\title{
1 Environmental stressors induced strong small-scale phenotypic 2 differentiation in a wide-dispersing marine snail
}

3 Nicolás Bonel $^{1,2,3^{*}}$, Jean-Pierre Pointier ${ }^{4} \&$ Pilar Alda $^{1,2}$

4

5

6 Centro de Recursos Naturales Renovables de la Zona Semiárida (CERZOS—CCT—CONICET Bahía

7 Blanca), Camino de la Carrindanga km 7, Bahía Blanca 8000, Argentina.

${ }^{2}$ Consejo Nacional de Investigaciones Científicas y Técnicas (CONICET), Argentina.

${ }^{3}$ Centre d'Écologie Fonctionnelle et Évolutive, UMR 5175, CNRS-Université de Montpellier,

Université Paul-Valéry Montpellier-École Pratique des Hautes Études_-IRD, 34293 Montpellier Cedex

05, France.

${ }^{4}$ PSL Research University, USR 3278 CNRS-EPHE, CRIOBE Université de Perpignan, Perpignan,

18 France.

19

* To whom correspondence should be addressed: nicobonel@gmail.com (N. Bonel)

Running head: Small-scale phenotypic differentiation in a wide-dispersing snail

Key words: adaptive plasticity, shell characters, genital morphology, intertidal 


\section{ABSTRACT}

2 Heterogeneous environments pose a particular challenge for organisms because the

3 same phenotype is unlikely to perform best regardless of the types of stress it

4 encounters. To understand how species meet this challenge, we investigated the extent

5 to which contrasting environmental pressures induced ecological and phenotypic

6 responses in a natural population of a wide-dispersing marine snail at a small spatial

7 scale. We analyzed several traits of Heleobia australis (Rissooidea: Cochliopidae)

8 collected from heterogeneous, but highly connected, habitats from the intertidal area of

9 the Bahía Blanca estuary, Argentina. We also conducted molecular analyses by

10 amplifying the COI gene in individuals sampled from each habitat. We found that

11 subpopulations living in sympatry of $H$. australis exhibited a strong phenotypic

12 divergence in shell characters and body weight in response to thermal, saline, and

13 dehydration stress, crab predation risk, and parasitic castrators. We proved that this

14 differentiation occurred even early in life as most of the characters observed in juveniles

15 mirrored those found in adults. We also found a divergence in penis size in snails

16 collected from each habitat and raised in common garden laboratory conditions. The

17 molecular analyses confirmed that the individuals studied constituted a single species

18 despite the strong phenotypic differences among subpopulations. The small-scale

19 phenotypic differentiation suggests that $H$. australis experienced a fine-grained

20 environment where conditions imposed by different sources of stress favored the

21 expression of beneficial traits. We discuss the role of plasticity in shaping adaptive

22 phenotypic responses that increase the likelihood of persistence of subpopulations

23 facing environmental stressful conditions. 


\section{1. INTRODUCTION}

2 If organisms have difficulties in adapting to human-induced global change and fail to

3 track projected environmental changes, populations become vulnerable to decline and

4 extinction (Hill et al. 2011, Hoffmann \& Sgrò 2011). Phenotypic plasticity, a common

5 feature in nature across many taxa, is the ability of a single genotype to express different

6 phenotypes in dissimilar biotic or abiotic environments (Travis 1994, West-Eberhard

7 2003). Many studies indicate a role of adaptive plasticity in shaping phenotypic

8 responses as an effective mechanism that can greatly improve the conditions for

9 persistence of populations facing abrupt environmental shift by facilitating rapid

10 adaptation to the new selection pressures (Price et al. 2003, Ghalambor et al. 2007,

11 Chevin \& Lande 2009). Adaptive plasticity that places populations close enough to the

12 new favored phenotypic optimum, for directional selection to act, provides the first step

13 in adaptation to new environments on ecological time scales as long as costs to

14 maintaining and/or producing a plastic response are not substantially large, thus

15 constraining the evolution of plasticity (Price et al. 2003, Ghalambor et al. 2007, Chevin

$16 \&$ Lande 2009). In this sense, adaptive phenotypic plasticity is crucial for the long-term

17 persistence of populations facing new environmental stress brought about by human-

18 induced global change (Hill et al. 2011).

20 Temperate marine habitats, in particular the intertidal zone, exhibit great variability in

21 environmental factors mainly driven by the fall and rise of the tides, creating areas on

22 the shore that are alternately immersed and exposed (Denny \& Paine 1998, Bourdeau et

23 al. 2015). The transitional nature of the intertidal habitat from marine to terrestrial

24 conditions strongly influences the physiology and the ecology of intertidal organisms

25 due to, for instance, the increase in environmental harshness (e.g. desiccation, extremes

26 in temperature and salinity) along the vertical zonation of the intertidal area (Vermeij

27 1972, Denny \& Paine 1998, Mouritsen et al. 2018). From this perspective, intertidal

28 organisms, such as aquatic gastropods, are likely to exhibit increased phenotypic

29 plasticity in response to such environmental selective pressures (Berrigan \& Scheiner

30 2004).

32 Phenotypic variation in shell traits is particularly widespread in gastropods (Bourdeau et al. 2015) and their shells offer an easily measured and permanent record of how the 
1 organism responded to local abiotic (e.g. water chemistry, temperature) and biotic (e.g.

2 predation, parasitism) agents (Dillon et al. 2013). Major environmental factors as

3 prolonged submersion times, desiccation, high temperature, and extreme salinity across

4 the vertical zonation create contrasting pressures that give rise to opposite shell trait

5 responses (Struhsaker 1968, Johannesson \& Johannesson 1996). For instance,

6 prolonged submersion times enhance foraging times and the absorption of calcium

7 carbonate from water leading to higher shell growth rates, which result in larger and

8 narrower shells and increased body mass (Vermeij 1973, review by Chapman 1992 2 ). By

9 contrast, snails from upper intertidal habitats that are periodically exposed to hot and

10 dry conditions and have only a limited time each day to feed exhibit the opposite shell

11 and body mass responses and are characterized by having a smaller aperture size, which

12 has been correlated to an increase in resistance to high desiccation in upper intertidal

13 habitats (Vermeij 1973, Chapman 1995, Melatunan et al. 2013).

Predators are one component of the heterogeneity across the intertidal zone because

they are often distributed patchily in time and space creating a steep selection gradient in predation risk, which, in turns, can promote adaptive shell responses (Appleton \& Palmer 1988, Palmer 1990, Boulding \& Hay 1993, Hollander et al. 2006, Bourdeau 2011). The adaptive value of predator-induced plasticity primarily linked to shell defenses are not limited to shell thickening (more resistant to crushing) as snails are capable of plastically altering different aspects of their shell shape (i.e. increased globosity; lower shell length to width ratio) or aperture (i.e. more elongated; higher aperture length to width ratio), which prevents the crab from pulling the soft parts out of the shell (Johannesson 2003, Dillon et al. 2013, Bourdeau et al. 2015). However, not all phenotypic plasticity triggered by environmental conditions is adaptive (Ghalambor et al. 2007). Some plastic trait responses, usually those imposed by the biochemistry and physiology of the organism, can be reversed over short time scales, which is not the case for developmental plasticity as it tends to be irreversible or takes longer to be reversed (Pigliucci et al. 2006). Parasites, for instance, can induce morphological, behavioral, and physiological change of individual snail hosts thereby influencing several aspects of host life history that can significantly alter size structure, demography, resource use, and intra and interspecific interactions of host population 
1 reported to induce changes in microhabitat choice (Curtis 1987) and in body size in

2 snails (Mouritsen \& Jensen 1994, Probst \& Kube 1999, Levri et al. 2005, Miura et al.

3 2006, Alda et al. 2010). Such pressure exerted by parasites also differs along the

4 intertidal zone (Smith 2001, Alda et al. 2010, 2019) and can cause important shifts in

5 the expression of host phenotypic traits, creating pronounced phenotypic differences

6 between infected and uninfected hosts (Poulin \& Thomas 1999, Fredensborg et al.

7 2006).

9 Despite the intertidal area spans a strong selective gradient, small-scale phenotypic

10 differentiation and adaptation of wide-dispersing organisms has been understudied

11 (review by Sanford \& Kelly 2011). These contrasting conditions along the vertical

12 distribution pose a particular challenge for wide-dispersing intertidal organisms: the

13 same phenotype is unlikely to perform best regardless of the types of stress it

14 encounters. We can then have as a result (i) a generalist phenotype (probably with

15 maladaptation), (ii) a phenotypic plasticity promoting different phenotypes under

16 different conditions, or (iii) a local genetic differentiation, contributing to the

17 phenotypic variation between habitats, favored by restricted gene flow through habitat

18 selection (and probably partial genetic isolation leading to ecotype formation). For

19 instance, limited gene flow can occur when habitat conditions disrupt larval dispersal

20 thereby increasing localized recruitment (Struhsaker 1968, Johnson et al. 1994, Parsons

21 1997, Levin et al. 2006), namely ‘phenotype-environment mismatch' (reviewed in

22 Marshall et al. 2010), whereat individuals would be subjected to local biotic and abiotic

23 stressors (Johannesson \& Johannesson 1996, Westram et al. 2021). Hence, to

24 understand how species meet this challenge, the first step is to observe phenotypic

25 variation and its association in the field with microhabitats characterized by different

26 sources of stress. If we observe different phenotypes associated with different

27 conditions, the next step is to explore whether such phenotypic variation results from a

28 direct impact of stress (e.g. trait shift induced by parasites) or is it because we are

29 dealing with ecotypes that find alternative niches (e.g. different microhabitats)

30 preventing, for instance, reproduction.

32 Here we tested how contrasting biotic and abiotic conditions across the intertidal

33 gradient affected snail density and induced different phenotypic responses at a small 
1 spatial scale among individuals from different subpopulations living in sympatry of a

2 wide-dispersing intertidal snail. We expected that snail density and most of mean values

3 of phenotypic traits measured shifted to lower values in habitats with high physical

4 stress conditions (thermal, saline, and dehydration stress), crab predation risk, and

5 parasite pressure. To test this, we collected and measured shell traits, weighted, and

6 dissected the mud snail Heleobia australis (d'Orbigny, 1835) (Rissooidea:

7 Cochliopidae) over the four seasons throughout a year from three distinct, but highly

8 connected, habitats from the intertidal area of the Bahía Blanca estuary, Southwestern

9 Atlantic, Argentina. Then, we collected juveniles from each habitat and raised them in

10 common garden laboratory conditions until they were adults to investigate if genital

11 morphology varied. Finally, we explored whether individuals living in these contrasting

12 habitats belong to the same species, and not to a species complex, by amplifying the

13 cytochrome oxidase subunit 1 (COI) gene. Altogether, we found clear evidence of

14 small-scale phenotypic differentiation in all traits likely as a result of environmental

15 pressures imposed by a strong biotic and abiotic stressors across the vertical distribution

16 of the intertidal area.

18 2. MATERIAL AND METHODS

\section{$19 \quad$ 2.1. Study species}

20 The intertidal mud snail Heleobia australis (previously known as Littoridina australis)

21 has a wide geographic range inhabiting marine and estuarine ecosystems from tropical

22 to temperate regions (from Brazil: $22^{\circ} 54^{\prime} \mathrm{S}$, to Argentina: $40^{\circ} 84^{\prime} \mathrm{S}$; De Francesco \&

23 Isla 2003) and is the most common benthic macrofaunal species in the estuaries and

24 coastal lagoons (De Francesco \& Isla 2004). In the Bahía Blanca estuary, there are no

25 other competing organism to $H$. australis as this snail species is the dominant

26 gastropod (Elías et al. 2004). It is a gonochoristic species with internal fertilization

27 (Neves et al. 2010). Mature females lay egg capsules, containing one fertilized egg

28 (Neves et al. 2010), preferably on shells of conspecific individuals, but they may also

29 be laid on shells of other species, on sand grains, or algae, which later develop into a

30 veliger larva that exhibits a short pelagic larval life (Neves et al. 2010), which is, on

31 average, $10 \pm 3$ days in standard laboratory conditions $\left(12: 12\right.$ photoperiod, $25^{\circ} \mathrm{C}$, water

32 salinity 30 PSU, and ad libitum food in the form of boiled ground lettuce; Bonel,

33 unpublished data). Adult snails attain a maximum shell size ranging from 7 to $8 \mathrm{~mm}$ 
1 with an average shell length of $5.2 \mathrm{~mm}(0.5 \mathrm{SD}$; this study) and a lifespan of 2.9 years

2 in a temperate climate and two well-defined recruitment episodes (De Francesco \&

3 Isla 2004, Carcedo \& Fiori 2012). However, in tropical and subtropical areas breeding

4 and recruitment occur year-round (Neves et al. 2010) suggesting that it is likely that $H$.

5 australis have shorter generation times. This species is capable of creating an air

6 bubble inside its pallial cavity, allowing juveniles and adults to temporarily float in the

7 water column, whereat they are carried along by the tide and wind driven current

8 (Echeverría et al. 2010), increasing its dispersion potential. Moreover, H. australis is

9 an obligate intermediate host of a large diversity of parasites that infect several other

10 species hosts. For instance, H. australis has been reported to host 18 larval trematode

11 species and 16 of these were from the Bahía Blanca estuary (Argentina), being all but

12 one parasitic castrators, with an individual worm eventually filling up the digestive

13 gland and gonad of the snail host (Alda \& Martorelli 2014).

\subsection{Study area and (a)biotically heterogeneous habitats}

This study was conducted in the Villa del Mar saltmarsh-mudflat located in the middle reaches of the Bahía Blanca estuary, Argentina ( $\left.38^{\circ} 51^{\prime} \mathrm{S}-62^{\circ} 07^{\prime} \mathrm{W}\right)$. The intertidal mudflat extends for more than $1 \mathrm{~km}$ across the tidal gradient. Its topography is characterized by a very gently sloping ramp on the seaward side (Pratolongo et al. 2009) and affected by strong semidiurnal tides and high seasonal variation (Perillo et al. 2001). Close to the mean high tide level, marshes covered by cordgrass (Spartina alterniflora) form a narrow, $150 \mathrm{~m}$ wide strip of vegetation followed by a mudflat area with no vegetation (Pratolongo et al. 2010). During low tide, these upper areas of the intertidal zone are subjected to high desiccation and temperature and salinity fluctuations as the tide takes ca. 10 hours to cover them (P. Pratolongo, personal communication; 26 February 2019) whereas low areas located close the seaward edge remain covered by water during low tide.

The existence of a tidal cycle exposes $H$. australis to extreme, but predictable, changes in abiotic conditions (at least twice every day) likely determining their vertical distribution (zonation patterns). Snails in the upper intertidal zone must remain quiescent for long periods of time during daylight hours or during low tide, being 
1 zone, which remain cover by water during low tide. The intertidal zone can therefore be

2 characterized in three distinct habitats: flats, marshes, and pans. Flats and marshes are

3 located in the upper zone and they drain at low tide, though flats are free of vegetation

4 and marshes are covered by cordgrass. Pans are free of vegetation but remain covered

5 by water during low tide and are located close the seaward edge. Thermal, saline, and

6 dehydration stress are strong selective forces occurring mainly in the upper intertidal

7 area (flats and marshes; Denny \& Paine 1998, Bourdeau et al. 2015) whereas these

8 inducing agents are weaker in pans, which exhibit low environmental stress condition

9 (Fig. 1).

11 Biotic agents also vary along the vertical distribution of the intertidal zone (Fig. 1). On

12 the one hand, the grapsid crab Neohelice granulata is one of the most abundant

13 macroinvertebrates of intertidal areas of the SW Atlantic estuaries where it commonly

14 inhabits the upper vegetated area (marshes) but uses the entire intertidal zone (Spivak et

15 al. 1994, Alvarez et al. 2013, Angeletti et al. 2014, Angeletti \& Cervellini 2015). This

16 burrowing crab could exert a strong pressure on Heleobia australis since it can

17 drastically reduce snail density in vegetated areas due to an intense bioturbation activity

18 (Spivak et al. 1994, Alvarez et al. 2013, Angeletti et al. 2014, Angeletti \& Cervellini

19 2015) and/or through snail predation (D'Incao et al. 1990, Barutot et al. 2011).

20 Although the main predator in the intertidal mudflat are crabs, there are other potential

21 predators such as snail-eating birds (e.g. Charadrius spp.) that occasionally feed on $H$.

22 australis (Martorelli 1991, Ieno et al. 2004, Meerhoff et al. 2013). For instance, in the

23 study area, $H$. australis has been reported to be one of the 39 dietary items consumed by

24 the White-Backed Stilt (Petracci \& Delhey 2005). On the other hand, parasite pressure

25 also differs along the intertidal zone. Trematode infection not only inevitably leads to

26 snail castration reducing its fitness to zero (Alda et al. 2019) but also gives rise to

27 smaller shell-sized morphs for infected snails (Alda et al. 2010). The prevalence

28 (percentage of individuals infected) of trematodes is higher in the lower area of the

29 intertidal zone, where parasite infection is predominately caused by one extremely

30 prevalent trematode, Microphallus simillimus. Such pressure is stronger in pans than in

31 flats and marshes because prolonged submersion times allow snails to increase time

32 spent foraging and thus ingesting parasite eggs (Alda et al. 2019). 
1 2.3. Field sampling and laboratory procedure

2 We sampled individuals of the intertidal mud snail H. australis in summer (March 6),

3 autumn (July 15), winter (September 20), and spring (December 7) of 2012 from the

$4 \quad$ study area. We performed an intense sampling in three contrasting intertidal habitats

5 from the Villa del Mar saltmarsh-mudflat because our aim was to test for phenotypic

6 variation in Heleobia australis at a small-spatial scale $(<1 \mathrm{~km})$ and because marine

7 environmental conditions in this location are representative of conditions found at other

8 sites from the Bahía Blanca estuary (Piccolo \& Hoffmeyer 2004). We followed a simple

9 random sampling by area for polygon study areas. We used QGIS 1.7 (https://qgis.org)

10 to define the sampling zone and to randomly distribute the points where the circular

11 quadrats were placed. Specifically, during low tide and from each biological zone from

12 the intertidal area (flats, marshes, and pans), we sampled snails by laying down nine

13 circular quadrats with $10 \mathrm{~cm}$ diameter and $2 \mathrm{~cm}$ deep (Area $=78.5 \mathrm{~cm}^{2}$ ) to get a

14 representative sample of each zone (e.g. Milroy 2015). Snails were sieved and washed

15 from the sediment through a 1-mm mesh, and immediately transported alive to the

16 laboratory in 0.5-1 plastic bottles filled with in situ water where they were kept in

17 aquaria and fed ad libitum with flake fish food. We repeated this procedure for each

18 sampling date.

20 Once in the lab, we counted the total number of snails in each of the nine samples (i.e.

21 samples A to I) taken from each habitat (flats, marshes, or pans) and sampling date.

22 From each sample, we arbitrarily decided to subsample $60 \%$ of individuals from each

23 sample to check for parasite infection, $30 \%$ for shell and body weight, and $10 \%$ for

24 parasite biomass. Because Heleobia australis is rather a small snail (mean shell length =

25 5-6 mm), it is hardly impossible to determine with the naked eye whether individuals

26 are phenotypically different from one another. Thus, as the probability of choosing each

27 individual was equal, we assumed that subsampling was done at random. Overall, our

28 large dataset consisted of 6,250 individuals, which were used to account for infected

29 and uninfected snails (hereafter infection status), and the remaining uncrushed snails

30 were used to estimate snail shell and body weight ( $\mathrm{n}=3,057$; see below) and parasite

31 biomass ( $\mathrm{n}=1,060$; data not showed in this study). All 10,367 snails were used to

32 estimate snail density and were also photographed using a camera attached to a

33 dissecting microscope to analyze shell and aperture morphometrics (see below). 


\section{$1 \quad$ 2.4. Snail density and infection status}

2 To test how contrasting habitat conditions affected snail density, we counted all

3 sampled individuals per habitat and sampling date to analyze spatial and temporal

4 variation of snail density. Then, to determine infection status, snails from each habitat

5 were crushed using a mortar and a pestle, tissue was examined under a dissecting

6 microscope, and trematodes were identified under a compound microscope following

7 Alda \& Martorelli (2014). Previous studies show that the most prevalent parasite in the

8 study area is Microphallus simillimus (Microphallidae), which makes up $87 \%$ of the

9 overall prevalence (Alda \& Martorelli 2014, Alda et al. 2019). This parasite has life

10 history traits such as abbreviated life cycle (the same snail host can serve as the first-

11 and second-intermediate host), meaning that once snails ingest parasite eggs, the

12 metacercariae encyst within the sporocyst in the infected snail, thereby maximizing

13 transmission success (Alda \& Martorelli 2014). One possible approach to the

14 contribution of parasites to the phenotypic variance in host populations is to compare

15 phenotypic responses of uninfected and infected hosts maintained under identical

16 conditions (Poulin \& Thomas 1999). Thus, to test for this, we only considered snails

17 infected by the most prevalent trematode $M$. simillimus and also from pans (the habitat

18 with the highest prevalence; Alda et al. 2019), which implies that both infected and

19 uninfected snails grew in the same environmental conditions. By doing so, we can

20 ensure that differences in phenotypic responses can only be attributed to M. simillimus

21 effect and not caused by other trematodes or habitat stress conditions.

As older hosts have greater cumulative risk of infection than do young hosts, each sample should be standardized by age, collected at the same time from an area in which hosts are likely to mingle and where they have experienced relatively uniform risks of infection (Lafferty et al. 1994). We therefore identified age cohorts by means of the length-frequency distributions in each sampling date and habitat and removed those individuals outside the lower $95 \%$ confidence limit of the cohort with larger individuals (see Text S1 in the appendix for details; Fig. S1).

\subsection{Shell and aperture morphometric}

32 To analyze variation in shell morphometric across habitat conditions and infection

33 status, we measured four linear variables from each photograph using ImageJ software: 
1 shell length (SL), shell width (SW), aperture length (AL), and aperture width (AW).

2 We chose the linear morphometric measurements approach over the geometric

3 morphometrics analysis because the landmark-based approach has a methodological

4 limitation that is the small number of individuals $(n<600)$ than can be analyzed (e.g.

5 (Carvajal-Rodríguez et al. 2005, Conde-Padín et al. 2007, Guerra-Varela et al. 2009,

6 Dillon et al. 2013, Larsson et al. 2020) while the classical approach followed in our

7 study allowed us for measuring more than 10,000 snails.

9 Similar to some other caenogastropod species (e.g. Littoridina sp.), the shell of $H$.

10 australis is generally small and conical and the axis of coiling lying at an angle of about

$1145^{\circ}$ above the plane of the elliptical aperture (Vermeij 1973, Hershler \& Thompson

12 1992). We estimated the shell volume as proxy of shell size by calculating the volume

13 of a cone (or double cone) because is a more reliable measure to describe shell size than

14 only considering a linear measurement such as shell length:

Shell size: Volume of a cone $=1 / 3 \pi(\mathrm{SW} / 2)^{2} \mathrm{SL}$

To analyze the shell shape, we estimated the SL to SW ratio. Likewise, we analyzed aperture shape by calculating the AL to AW ratio. We used AL and AW to calculate aperture size by calculating the area of an ellipse:

\subsection{Shell thickness and body mass}

To test whether snails subjected to a stronger predation pressure exhibit thicker shells, (considered to be a shell defense trait against predators as it is more resistant to crushing; (Johannesson 2003, Dillon et al. 2013, Bourdeau et al. 2015) and whether contrasting environmental stress conditions affected body mass, we estimated and compared shell weight and ash-free dry-weight among habitats. We used a subsample of individuals $(n=70)$, representative of the population shell length-frequency distributions obtained previously for all individuals sampled on each date and habitat. the organic content of the snail as ash-free dry weight (AFDW, calculated as the 
1 difference between the dry weight and the weight of the incombustible component of

2 the shell), which was considered as body mass. To achieve this, we dried snails

3 individually in porcelain crucibles for $48 \mathrm{~h}$ at $60{ }^{\circ} \mathrm{C}$, weighed them with a digital scale

4 (precision $0.1 \mathrm{mg}$ ), ashed the snails for $5 \mathrm{~h}$ in a muffle furnace at $500{ }^{\circ} \mathrm{C}$ and then

5 reweighed them (Bonel \& Lorda 2015). The ash shell weight (the incombustible

6 component of the shell) was considered as proxy of shell thickness (e.g. Palmer 1981)

7 and used to estimate and compare its variation among individuals along the vertical

8 gradient of the intertidal area.

\section{$10 \quad$ 2.7. Variation in penis size}

11 To test for differences in genital morphology, we analyzed variation in the penis size and morphology of individuals from contrasting habitats conditions living in sympatry but raised in common garden laboratory conditions. Genital morphology is one of the most widely-used trait when studying the internal anatomy of gastropods, especially among cochliopids (Liu et al. 2001). Reproductive anatomy is very useful to delineate species since they tend to show more variation among than within species and penis morphology, in particular, is used when delineating Heleobia species (Gaillard \& Castellanos 1976). We sampled snails of $H$. australis from the three distinct habitats of the intertidal area of the Villa del Mar saltmarsh-mudflat in November (Spring) of 2017. Snails were transported to the lab and they were split into adults and juveniles based on their shell-length distribution (as mentioned above). Adults were preserved in alcohol 96\% and used to conduct molecular analysis. Because field-collected snails may retain the influence of environmental conditions experienced prior to collection even in early life stages (Sanford \& Kelly 2011), we tried to minimize this potential effect by considering only the smallest individuals sampled from each habitat (mean shell length, $\mathrm{SD}: 4.15 \pm 0.36 \mathrm{~mm})$. Juveniles were placed in three different aquaria per habitat to prevent tank effects. The snail abundance at the onset of the experiment was similar in each set of aquaria to minimize potential density-dependent effects (flats: $\mathrm{n}=38.3 \pm$ 0.6; marshes: $n=43.7 \pm 0.6$; pans: $n=46.7 \pm 0.6$ ). Juveniles were kept in common garden laboratory conditions (12:12 photoperiod, $25^{\circ} \mathrm{C}$, water salinity $30 \mathrm{PSU}$, and $\mathrm{ad}$ libitum food in the form of boiled ground lettuce) for 21 months, which ensured that all individuals considered in the analysis were adults. Prior to dissection, we collected, on average, 30 snails from each aquaria and preserved them in the Railliet-Henry's 
1 solution (930 $\mathrm{ml}$ distilled water, $6 \mathrm{~g} \mathrm{NaCl}$ [0.85\%], $50 \mathrm{ml}$ formaldehyde [37\%], $20 \mathrm{ml}$

2 glacial acetic acid). Then, they were all dissected under the dissecting microscope and

3 the reproductive system of $c a .15$ males per aquarium was drawn using a camera lucida

4 attachment (Pointier et al. 2004). These were scanned and the penis surface area was

5 calculated using the ImageJ software. Shells were photographed and analyzed as

6 mentioned above to estimate shell size and shape.

\section{$8 \quad 2.8$. COI analysis}

9 To confirm that individuals living in these contrasting habitats belong to the same

10 species and not to a species complex, we conducted molecular analyses by amplifying

11 the cytochrome oxidase subunit 1 (COI) gene in 10 individuals sampled from each of

12 the three sites. Then, we built a gene tree and a haplotype network to verify if

13 individuals gather in clusters depending on the habitat they come from. We also applied

14 a species-delimitation method: Automatic Barcode Gap Detection (ABGD, Puillandre et

15 al. 2012). ABGD detects barcode gaps, which can be observed whenever the divergence

16 among organisms belonging to the same species is smaller than divergence among

17 organisms from different species (see Text S2 in the appendix for specific details on

18 these procedures).

\subsection{Statistical analyses}

21 To test for spatial and temporal variation of snail density, we performed a two-way

22 ANOVA including habitats (flats, marshes, and pans) and seasons (summer, autumn,

23 winter, spring) as fixed effect, and their interaction. We transformed density (natural-

$24 \log$ ) data to meet assumptions of normality and homoscedasticity.

26 To test for phenotypic variation in shell characters, we defined three categories (cat.) of

27 snails that comprised: ( ) uninfected adults, (ii) infected adults, and (iii) uninfected

28 juveniles. These three categories (cat. $i-i i i)$ were considered to test whether contrasting

29 (a)biotic stress conditions (environmental stress and crab predation) induced variation in

30 shell traits (morphometric and thickness) and body mass. To evaluate the effect exerted

31 by the trematode Microphallus simillimus on shell morphometry of Heleobia australis

32 from pans (the habitat with the highest prevalence), we created a fourth category that

33 included uninfected and infected adult snails (cat. $i v$ ). We performed four Principal 
1 Components Analyses (PCAs) to visualize the main components of the morphological

2 shell variation for each snail category. Then, we tested for differences in shell

3 morphology (size and shape of the shell and aperture) by fitting independent linear

4 mixed models (LMMs), with a Gaussian error distribution, for the above-mentioned

5 four categories (cat. $i-i v)$.

7 To test the effect of habitat conditions on shell traits (cat. $i$-iii), we considered habitat as

8 a fixed effect. To test for morphometric differences between infected and uninfected

9 (cat. $i v$ ), we included infection status (infected and uninfected) as a fixed effect as we

10 only considered individuals from one habitat (i.e. same habitat conditions for infected

11 and uninfected snails). For all the four categories (cat. $i-i v$ ), we included sex (male and

12 female) as a fixed factor (and its interaction with habitat or infection status). We added

13 sampling season as a random factor in all models as it can explain a significant portion

14 of the variance in measured variables. Likewise, we also considered shell size as a

15 covariate when testing for shell and aperture shape, but the models were all ran with and

16 without this effect to check the extent to which the effects were mediated by shell size.

17 We also incorporated shell size as a covariate when testing for shell and body weight

18 (by means of LMMs) and estimates were statistically corrected for variation that could

19 be explained by the covariate. Statistical significance of the fixed effects was obtained

20 from model comparisons using likelihood-ratio tests. Random effects were separately

21 tested using chi-square likelihood-ratio tests with the corrections indicated by Zuur

22 (2009). To test for differences in penis size (area of the penis), we performed a linear

23 model with habitat as a factor and we added shell size (volume) as a covariate, which

24 was used to statistically correct estimates for variation explained by the covariate. All

25 individuals analyzed were free of parasites, meaning that the differences found are not

26 due to parasite effect.

28 Post-hoc tests were performed when the effects were significant $(P<0.05)$, using Holm-

29 Bonferroni correction for multiple testing to compare their effects. Values are given as

30 means $\pm 1 \mathrm{SE}$ unless otherwise stated. All analyses and figures were performed with $\mathrm{R}$

31 v.3.3.3 packages lme4 (Bates et al. 2014), nlme (Pinheiro et al. 2017), car (Fox et al.

32 2011), effects (Fox 2003), MASS (Ripley et al. 2013), plyr (Wickham 2011), dplyr

33 (Wickham et al. 2019a), devtools (Wickham et al. 2019b), ggbiplot (Vu 2011), psych 
1 (Revelle 2018), ggplot2 (Wickham \& Chang 2008), and outliers (Komsta 2011).

\section{3. RESULTS}

\section{3.1. Overview}

5 Overall, the mud snail Heleobia australis showed a strong variation in snail density and

6 a remarkable variation in several traits linked to contrasting biotic and abiotic pressures

7 (environmental stress, predation, or parasite infection) occurring along the vertical

8 zonation of the intertidal area. Tables 1 to 3 summarize descriptive statistics on density

9 and shell traits measured for the first and fourth snail categories (cat. $i$ and $i v$ ). In the

10 appendix, we reported results of the snail density split by age classes (juvenile and

11 adult; Table S1), principal components analyses (Text S3, Table S2, Fig. S3),

12 descriptive statistics and the linear mixed models for the four snail categories on shell

13 traits (Tables S3-S8) and for shell weight and body mass (Table S9).

\subsection{Strong habitat and seasonal effect on snail density}

16 We found spatial differences in total density (including juveniles and adult snails; Table

17 1; Fig. 2). We observed no significant interaction between habitats and seasons $\left(F_{(6,106)}\right.$

$18=1.56, P=0.167)$. Marshes showed the lowest density whereas flats and pans showed a 19 marginal non-significant difference (Table 1). We found significant differences between 20 seasons (Table 1). Density was higher in spring than in autumn, winter, and summer

21 (Table 1). Snail density in autumn did not differ from that of summer or winter, these

22 latter two being not different either (Table 1), but it largely increased from autumn to

23 spring (particularly in pans as compared to flats and marshes; Fig. 2). This increase

24 across seasons was mainly driven by juvenile recruitment (Table S1; Fig. S2). By

25 contrast, the effect of habitat conditions and seasons on adult density showed a

26 significant interaction because density was higher in pans from autumn to winter

27 whereas it decreased in marshes for the same period, and in flats it decreased from

28 summer to autumn and the than remained fairly constant (Table S1; Fig. S2).

\section{3.3. Strong habitat effect on shell morphometrics}

31 The morphometric responses to habitat conditions were similar in all the three snail 
1 uninfected adult snails (cat. $i$ ) in the main text and those for infected adults (cat. $i i$ ) and

2 juvenile snails (cat. iii) are shown in the appendix (Tables S4-S7; Figs. S4-S5).

3

4 3.3.1. Shell size. We found a significant interaction between fixed effects (habitat and

5 sex; $\left.X_{2}^{2}=8.42, P=0.015\right)$. This was mainly driven by differences in this trait between

6 sexes in pans, whereas such difference between males and females was not detected in

7 snails from flats and marshes. In other words, males exhibited a larger shell size $\left(\mathrm{mm}^{3}\right)$

8 compared to females in pans, meaning that the sex effect was much stronger in creating

9 size differences between sexes compared to flats and marshes where the sex effect was

10 weaker resulting in no difference in size between sexes. By contrast, the effect of habitat

11 conditions was stronger in both sexes. Both male and female snails from flats and

12 marshes showed a smaller shell size (a decrease of 12 and $22 \%$ in shell size;

13 respectively) relative to individuals from pans (Tables 2 and S3; Fig. 2).

3.3.2. Shell shape. The interaction between fixed effects was significant $\left(X^{2}{ }_{2}=8.20, P=\right.$ 0.017 , but when we statistically corrected for shell size, it became marginally nonsignificant $\left(X_{2}^{2}=5.69, P=0.058\right)$. Snails from pans (sex pooled) exhibited the most elongated shells relative to individuals from marshes and flats. At the sex level (habitats pooled), males had a more elongated shell shape than females (Table 2 and S3; Fig. 2).

3.3.3. Aperture size. We found a strong habitat and sex effect on aperture size; the interaction between these variables was not significant $\left(X_{2}^{2}=3.05, P=0.217\right)$. Across habitats (sex pooled), snails from pans showed the largest aperture size $\left(\mathrm{mm}^{2}\right)$ whereas in flats and marshes it was 9 to $12 \%$ smaller, respectively. Moreover, we observed a significant difference in aperture size between sexes (habitats pooled), males had bigger apertures than females and this difference was consistent across habitats (Table 2 and S3; Fig. 2).

3.3.4. Aperture shape. We found no significant difference in aperture shape between sexes $\left(X^{2}{ }_{1}=0.65, P=0.724\right)$, and this pattern was similar even after correcting for shell size $\left(X_{2}^{2}=2.20, P=0.333\right)$. However, individuals from pans (sex pooled) showed the most rounded shape relative to those from flats and marshes, which showed a more elongated aperture shape (Table 2 and S3; Fig. 2). 


\subsection{Pronounced trematode effect on shell morphometric}

3 Infection caused by the trematode $M$. simillimus strongly shifted the mean value of most

4 phenotypic traits of $H$. australis to lower values when comparing infected and

5 uninfected snails from pans.

6

7 3.4.1. Shell size. Shell size of infected snails (sex pooled) decreased $10 \%$ relative to

8 uninfected ones, whereas females (infection status pooled) were 5\% smaller than males

9 (Table 3; Fig. 4). We found no significant interaction between the fixed effects (status

10 and $\left.\operatorname{sex} ; X^{2}=0.70, P=0.402\right)$.

3.4.2. Shell shape. We found a significant interaction between status and $\operatorname{sex}\left(X^{2}{ }_{1}=\right.$ 15.86, $P<0.001)$. This was because, at the status level, uninfected males were more elongated (higher SL to SW ratio) than uninfected females, but infected males and females showed no difference in shell shape. We found the same pattern at the sex level; that is, infected male and female snails have a more elongated shell relative to uninfected male and female individuals (Table 3; Fig. 4).

3.4.3. Aperture size. We observed a strong effect of infection status and sex in aperture size. Infected snails (sex pooled) and females (status pooled) had a smaller aperture than uninfected and male snails (15 and 3\% respectively; Table 3; Fig. 4). We found no significant interaction between fixed effects $\left(X^{2}{ }_{1}=2 \mathrm{e}-04, P=0.990\right)$.

3.4.4. Aperture shape. Uninfected snails exhibited a more elongate aperture shape this shell trait (Table 3; Fig. 4). We found no significant interaction between fixed effects and no sex effect on aperture shape, even after correcting by shell size $\left(X^{2}{ }_{1}=\right.$ $0.33, P=0.564)$.

\subsection{Thicker shells and lower body mass in habitats with high (a)biotic stress}

31 We found that snails differed in shell weight ( thickness) across habitats $\left(X^{2}{ }_{2}=48.93\right.$, $P<0.001)$. Snails from pans showed the lightest/thinnest shells $(11.53 \pm 0.23 \mathrm{mg})$ 
$1 \quad\left(12.00 \pm 0.15 \mathrm{mg} ; P_{\text {Pans }<\text { Flats }}=0.001\right)$. By contrast, in marshes individuals showed the

2 heaviest/thickest shells $\left(P_{\text {Marshes }>\text { Flats }}<0.001\right.$; Fig. 4). Body mass also differed across

3 habitats $\left(X_{2}^{2}=19.67, P<0.001\right)$. Snails from pans exhibited the heaviest body mass

$4 \quad(0.50 \pm 0.05 \mathrm{mg})$ relative to individuals from marshes $(0.32 \pm 0.03 \mathrm{mg})$ and flats

$5 \quad(0.33 \pm 0.04 \mathrm{mg})\left(P_{\text {Pans }>\text { Marshes }}<0.001 ; P_{\text {Pans }>\text { Flats }}<0.001\right)$, which showed no differences in

6 body weight $\left(P_{\text {Marshes }<\text { Flats }}=0.390\right.$; Fig. 5). Further details on observations, corrected and

7 uncorrected mean values, and statistics are indicated in the appendix (Text S4; Table

8 S9; Fig. S6).

\section{3.6. Variation in penis size}

11 The penis shape confirmed that individuals from each habitat of the Bahía Blanca

12 estuary belong to the same species (Fig. S8; Gaillard \& Castellanos 1976). We found,

13 however, a clear difference in penis size $\left(F_{(2,39)}=8.42, P<0.001\right)$. Individuals from

14 marshes showed the largest size relative to flats $\left(P_{\text {flats }}<\right.$ marshes $\left.<0.001\right)$ and pans

$15 \quad\left(P_{\text {pans }<\text { marshes }}=0.034\right)$; snails collected from these two habitats showed a marginal non-

16 significant difference $\left(P_{\text {flats }<\text { pans }}=0.090\right.$; Fig. 6). We found no significant effect of shell

17 size, meaning that differences in penis size were not due differences in individual's shell

18 size $\left(F_{(1,39)}=0.27, P=0.608\right)$. Further, we found no differences in shell shape, even after

19 controlling by shell size $\left(F_{(2,43)}=0.851, P=0.435\right)$.

\subsection{Molecular analysis of the cytochrome oxidase subunit 1 (COI) gene}

The species-delimitation analysis implemented in ABGD found only one partition (prior maximal distance, $P=0.001$ ) that confirmed that the individuals here studied constitute a single Heleobia species, which is in agreement with the similar penis shape found among habitats. In fact, we did not observe any type of structure among individuals. The gene tree and haplotype network showed that individuals did not gather in clusters depending on the habitat they come from (Figs. S8 and S9).

\section{DISCUSSION}

This study provides compelling evidence of ecological and phenotypic trait variation in response to contrasting biotic and abiotic conditions at a small spatial scale 
1 experienced a fine-grained environment where the combined effect of plasticity and

2 environmental pressures favored the expression of potentially beneficial traits at a local

3 scale.

\section{4.1. Reduced snail density under high environmental and predatory stress}

6 Density of Heleobia australis was the lowest in marshes (vegetated area that drains at

7 low tide) relative to flats (unvegetated area that drains at low tide) and pans (covered by

8 water at low tide) whereas flats and pans showed no difference. However, when

9 analyzed by age classes, adult density was higher in pans during winter but remarkably

10 lower in marshes, even compared to flats (both habitats from the upper area). This is

11 consistent with the idea that prolonged submersion times could increase the survival

12 rate of snails during harsh climatic conditions (Fig. S2). As for juvenile snails, their

13 density increased from autumn to winter in all the three habitats and kept increasing

14 until spring time where it was 1.6 and 2.4 times higher in pans relative to flats and

15 marshes, respectively (Table S1; Fig. S2). We found little support for the idea that

16 intense environmental stress, combined with harsh climatic conditions, could strongly

17 decrease their survival rate affecting their abundance, especially, in the upper area.

18 Instead, these findings suggest that conditions at pans might have favored juvenile

19 recruitment, which could explain the differences observed in spring.

It is puzzling, however, that total density in marshes was lower relative to flats because

H. australis is positively associated with marsh plants (the smooth cordgrass Spartina alterniflora, which dominates the lower marsh) as they buffer physical stress factors (thermal and dehydration stress) relative to uncovered areas, promoting snail aggregation (Cيanepucccia_et_al. 2007 and references therein). One possible explanation for the low density in marshes, relative to flats, is if this resulted from a negative interaction between $H$. australis and the grapsid crab Neohelice granulata, whose aggregation is also facilitated by marsh plants (Spivak et al. 1994, Alvarez et al. 2013, Angeletti et al. 2014, Angeletti \& Cervellini 2015) where it attains density peaks in late spring and early summer but it is absent throughout the year in unvegetated areas (flats or pans; (Angeletti \& Cervellini 2015). It is therefore likely that the low density of $H$. australis in vegetated crab-rich habitats resulted from an increased bioturbation activity caused by N. granulata, particularly during that period of time (Alvarez et al. 2013). 
1 Another mutually non-exclusive hypothesis is that this difference between marshes and

2 flats could result from a higher predation pressure caused by this crab (D'Incao et al.

3 1990, Barutot et al. 2011), in which case it might have induced predatory shell defenses

4 as shell thickening or narrower apertures (Boulding \& Hay 1993, Johannesson \&

5 Johannesson 1996, Rolán-Alvarez 2007, review by Bourdeau et al. 2015). Accordingly,

6 snails from marshes exhibited a strong variation in shell characters that support this

7 hypothesis, which we discuss later in this section.

9 4.2. Snails exhibited larger, narrower, and thinner shells and heavier body mass in 10 habitats with low stress conditions

11 Snails subjected to different levels of stress showed a strong phenotypic variation. In all categories analyzed (cat. $i-i i i)$, individuals showed a clear shift in their phenotype likely in response to different environmental pressures (Fig. 7). Overall, the distribution of trait values tended to represent two distinct groups, one for flats and marshes and another for pans. Such responses seem to be primarily linked to the level of exposure to physical stress (temperature and salinity fluctuation and desiccation) of individuals during low tide. Prolonged submersion times enhance foraging times and the absorption of calcium carbonate from water increasing shell growth rate, which, in turn, gives rise to larger but more elongated shells (review by Chapman 1995). As there is a maximal rate at which calcium carbonate can be absorbed from the water, rapidly growing individuals produce thinner shells for the same amount of body weight than slower growing individuals. This results in a larger internal volume allowing for accommodating a higher body mass, which is related to higher growth rate favored by longer foraging times (Palmer 1981, Kemp \& Bertness 1984, Chapman 1995, Trussell 2000a). Accordingly, snails that remain covered by water during low tide (pans) showed larger, narrower, and thinner shells and heavier body mass relative to individuals from habitats with high environmental stress conditions (flats and marshes). As higher body weight is directly linked to higher fecundity (i.e. egg production; Fredensborg et al. 2006), it is therefore likely that the heaviest body weight of individuals from pans was related to a higher recruitment, which would explain the increased juvenile abundance compared to flats and marshes (Fig. S2). 
1 Juvenile and adult snails from flats and marshes showed a smaller aperture size (smaller

2 aperture surface area) with respect to individuals from pans. It could be that higher

3 environmental stress conditions favored the expression of a smaller aperture size as a

4 potentially beneficial trait, thus increasing resistance to high desiccation in these

5 habitats that drain at low tide. This is consistent with other studies showing that the size

6 of the shell aperture in gastropods is smaller in response to hot and dry conditions

7 (Machin 1967, Vermeij 1973, Chapman 1995, Melatunan et al. 2013, Schweizer et al.

8 2019). Moreover, individuals from flats and marshes showed thicker shells and lower

9 body mass. Shell thickening could be due to a higher deposition of calcium carbonate at

10 a slow grow rate (likely in response to unfavorable conditions in more exposed habitats

11 from the upper intertidal) that traded off against investment in body mass (Palmer

12 1981).

\subsection{Crab predation pressure would favor the expression of shell defenses in}

\section{Heleobia australis}

Snails from marshes showed a more rounded and thicker shell, reduced body mass, and a narrow aperture shape for three snail categories analyzed (cat. $i$-iii; Fig. 7). Such characteristics are consistent with shell defenses probably induced by the high presence of the predatory crab Neohelice granulata in that habitat in particular (e.g. Appleton \& Palmer 1988, Palmer 1990, Bourdeau et al. 2015). Considering that crushing predators exert a strong selective pressure driving the evolution of behavioral, chemical, and morphological defense traits (Appleton \& Palmer 1988, Palmer 1990, Trussell 2000b, Johannesson 2003, Bourdeau et al. 2015), our results, combined with its remarkably low density, support the hypothesis that predation pressure is stronger in marshes than in flats and pans. Yet, specific information on whether crabs actively predates on $H$. australis is limited or inexistent. Earlier studies reported that $N$. granulata consumes mollusks but in a low frequency (D'Incao et al. 1990, Barutot et al. 2011). These studies, however, have used visual examination of gut/stomach contents. This procedure may have under-estimated true predation levels as crabs only eat the soft tissue after crushing/peeling the shell whereby the remains found in guts or stomach become unidentifiable due to maceration and digestion. Thus, further studies using molecularbased tools are needed for detecting the presence of Heleobia's tissue in crab's stomachs as an alternative or complementary approach to visual identification (e.g. 
1 Albaina et al. 2010, Collier et al. 2014). By doing so, we would be able to establish the

2 trophic link between these two species that is highly likely to exist. Evidence found in

3 this study clearly reveals that $H$. australis phenotypically responded to the presence of

4 predatory crabs, even early in life as juveniles from marshes also showed a narrow

5 aperture shape and a more rounded shell. Our results therefore warrant further

6 investigation to understand the adaptive value of the plastic shell responses of

7 gastropods induced by predators.

\section{4.4. Strong parasite effect on shell characters: a trade-off between growth and} 10 early reproduction

11 Infected and uninfected snails from pans showed a clear phenotypic differentiation in

12 shell traits. Trematode infection inevitably leads to snail host castration drastically

13 reducing host fitness, which, in evolutionary terms, is equivalent to death of the host

14 (Lafferty 1993, Fredensborg et al. 2006). In this sense, being castrated by a parasite is

15 similar as being eaten by a predator (Kuris 1974). This means that parasitic castrators

16 can exert a strong selective force that could favor the expression of behavioral,

17 physiological, and morphological adaptations to minimize the negative impact of

18 parasitism on host fitness (Lafferty 1993). Early maturation, which results from fast

19 growing individuals, is an effective strategy that increases current reproductive effort

20 over future reproduction (Cole 1954, Lewontin 1965, Roff 1992), which equals to 0 in

21 castrated hosts. In Heleobia, castration caused by Microphallus can have a profound

22 impact on snail fitness as this parasite shows an extensive host exploitation occupying

23 the entire gonad and most of digestive gland (see Fig. S2 in Alda et al. 2019).

Our results showed that infected snails had a more elongated shell shape but a smaller

26 size compared to uninfected snails (Fig. 7). Despite infected snails were smaller, they

27 exhibited the same number of whorls (six) as uninfected snails, which indicates that

28 individuals analyzed were adults (Gaillard \& Castellanos 1976). It could therefore be

29 that the elongated shape resulted from an initial higher growth rate (review by

30 Chapman, 1995) likely followed by an energy reallocation from growth to early

31 reproduction (Lafferty 1993, Agnew et al. 1999), which could explain the smaller shell

32 size compared to uninfected snails (Alda et al. 2010, 2019, this study). Infected snails

33 also showed a smaller aperture size but a more rounded shape relative to uninfected 
1 individuals (Fig. 7). This change in aperture size and shape could be a side effect of

2 selection for high rate of shell growth (Boulding \& Hay 1993) induced by parasites.

3 Together, these findings support the idea that infection by trematodes exerted a strong

$4 \quad$ selective pressure on the snail host causing important shifts in the expression of shell

5 traits towards lower mean values, creating a pronounced phenotypic difference between

6 infected and uninfected snails (Poulin \& Thomas 1999).

\section{4.5. Difference in penis size in a single Heleobia species}

9 Interestingly, individuals from each habitat showed a clear variation in penis size in

10 spite of they were raised in common garden laboratory conditions (no habitat effect)

11 and, when dissected, we observed that none of them was infected by parasites (no

12 parasite effect). Field-collected juveniles might retain the influence of environmental

13 conditions experienced prior to collection (Sanford \& Kelly 2011). Thus, one possible

14 explanation is that this variation resulted from different growth rates as well as the

15 differences in shell shape observed for wild snails. We found, however, no differences

16 in shell shape among male individuals reared in laboratory conditions, even after

17 controlling by shell size. It is noteworthy that a strong difference in penis size emerged

18 despite the relatively small number of male individuals analyzed ( $\mathrm{n}=15$ per habitat).

19 One interpretation of this phenotypic divergence is that it was not related to dissimilar

20 rates of growth but to genetic differences, suggesting that this is likely to be a non-

21 plastic trait. Despite the difference in size, its shape indicates that individuals from each

22 subpopulation belong to the same species, more specifically to Heleobia australis

23 australis (see Gaillard \& Castellanos, 1976 for further detail on taxonomy).

24 Accordingly, the COI gene confirmed that specimens considered in this study constitute

25 a single species.

27 Future experimental (laboratory breeding) and non-experimental approaches (multilocus

28 or genomic analyses) are needed to exclude other processes that may have contributed

29 to this difference in penis size. These approaches will help us to understand whether this

30 genital divergence could be an indicative of pre-zygotic reproductive isolation among

31 subpopulations of Heleobia australis living in sympatry (Kameda et al. 2009, Hollander

32 et al. 2013). If this is true, it could be that individuals studied herein would be part of a

33 species complex that have recently diverged, which would be in line with the lack of 
1 clusters when analyzing the conserved COI gene (Kemppainen et al. 2009, Janzen et al.

$2 \quad$ 2017, Matos $\square$ Maraví et al. 2019).

4 4.6. Does the small-scale phenotypic differentiation in Heleobia australis reflect 5 adaptive plasticity responses to local environmental pressures?

6 Theory predicts that adaptive phenotypic plasticity is more common than genetic

7 adaptation in wide-dispersing species relative to species with restricted dispersal

8 (Mather 1955, Levins 1968, Via \& Lande 1985, Scheiner 1998, De Jong 1999, 2005).

9 That is because gene flow homogenizes genotype frequencies across space countering

10 the effect of natural selection (review by Lenormand 2002). Our results suggest that

11 Heleobia australis experienced a fine-grained environment where conditions imposed

12 by contrasting biotic and abiotic stressors across the vertical gradient favored the expression of beneficial traits. This study was not designed to test for an adaptive basis to phenotypic trait variation, but provides a reasonable ground for advocating that the shifts in the mean trait values could be adaptations in response to the prevailing selection pressure at each habitat. If this is true, adaptive plasticity might have placed populations close enough to the new favored phenotypic optimum for directional selection to act, thus foreshadowing adaptive evolutionary responses over longer periods of time (Ghalambor et al. 2007).

The question that inevitably arises is whether there is scope for local adaptation in this intertidal mud snail. An increasing number of experimental studies indicates that local genetic adaptation may be more common than predicted by theory in marine species with planktonic dispersal, especially in systems characterized by strong selection over relatively fine spatial scale (Hays 2007, Marshall et al. 2010, Sanford \& Kelly 2011). One possible explanation for the evolution of locally adapted phenotypes in species with planktonic dispersal is linked to pre- and post-colonization barriers to connectivity (i.e. phenotype-environment mismatch) that increase localized recruitment (Levin et al. 2006, Marshall et al. 2010). That is, local adaptation may be ensured by genetic polymorphism because immigration is rare and the intrapopulation gene pool is highly reliant upon local recruitment whereat individuals are exposed to local selection pressures. Localized recruitment combined with directional selection of adaptive traits 
1 the most extreme phenotypes, the so-called Baldwin Effect, or more commonly known

2 as 'genetic assimilation' (reviewed in Waddington 1953, West-Eberhard 1989, Pigliucci

3 et al. 2006, but see West-Eberhard 2003). Only a few studies reported local genetic

4 differentiation in wide-dispersing marine snails, contributing to the phenotypic

5 differentiation, as a result of local disruption to dispersal of planktotrophic larvae, post-

6 veligers, and juvenile stages (e.g. Struhsaker 1968, Parsons 1997). In this context, it is

7 therefore plausible that the planktotrophic snail H. australis benefit from the combined

8 effect of directional selection and plasticity to evolve locally adapted phenotypes to

9 contrasting habitat conditions across the intertidal gradient.

\section{5. CONCLUSION}

12 Overall, our results showed that the same phenotype was unlikely to perform best regardless the stress encountered. Contrasting environmental stressors across the vertical gradient induced important shifts in the expression of phenotypic traits, thus creating pronounced small-scale phenotypic differences. These findings support the standpoint that phenotypic plasticity favored the expression of beneficial traits thereby increasing the likelihood of persistence of subpopulations facing local environmental stressful conditions. The next step is therefore to perform more powerful experimental approaches (including common garden designs and reciprocal transplants) and molecular analyses to unveil the adaptive value of the small-scale phenotypic plasticity in this marine snail. Future studies are clearly needed to understand the spatial scale at which adaptive differentiation can occur and the relative contributions of phenotypic plasticity versus fixed genetic variation in key traits of wide-dispersing marine organisms. Such information is critical for improving the prediction of the biological impacts of climate change and for effective conservation management approaches of marine system populations.

\section{ACKNOWLEDGEMENTS}

29 We would like to express our gratitude to Kevin Lafferty, Patrice David, Antonio A.

30 Vazquez Perera, Philippe Jarne, and Romain Villoutreix for their constructive

31 suggestions on earlier versions of the manuscript. We also thank Leandro A. Hünicken

32 and Micaela Folino for field and laboratory assistance and to Néstor J. Cazzaniga for

33 providing insightful comments on the systematics of Heleobia group. This manuscript 
1 was improved by comments from Dr. Sokolova and three anonymous reviewers. This

2 work was partially funded by a research grant from the Universidad Nacional del Sur

3 (UNS 24/B153 and UNS 24/B199). NB was partially supported by the "Programa de

4 Financiamiento Parcial de Estadías en el Exterior para Investigadores Asistentes",

$5 \quad$ National Scientific and Technical Research Council CONICET (Res. N ${ }^{\circ} 558$ 1236/08;

6 4118/16)".

7

\section{$8 \quad$ AUTHORS' CONTRIBUTIONS}

9 NB and PA conceived the ideas and designed methodology; NB, JPP, and PA collected the data; NB analyzed the data and led the writing of the manuscript. All authors contributed critically to the drafts and gave final approval for publication.

\section{REFERENCES}

14 Agnew P, Bedhomme S, Haussy C, Michalakis Y (1999) Age and size at maturity of the mosquito Culex pipiens infected by the microsporidian parasite Vavraia culicis. Proc R Soc Lond B 266:947-952.

Albaina A, Fox CJ, Taylor N, Hunter E, Maillard M, Taylor MI (2010) A TaqMan real-time PCR based assay targeting plaice (Pleuronectes platessa L.) DNA to detect predation by the brown shrimp (Crangon crangon L.) and the shore crab (Carcinus maenas L.) - Assay development and validation. J Exp Mar Biol Ecol 391:178-189.

Alda P, Bonel N, Cazzaniga NJ, Martorelli SR (2010) Effects of parasitism and environment on shell size of the South American intertidal mud snail Heleobia australis (Gastropoda). Estuar Coast Shelf Sci 87:305-310.

Alda P, Bonel N, Cazzaniga NJ, Martorelli SR, Lafferty KD (2019) A strong colonizer rules the trematode guild in an intertidal snail host. Ecology:e02696.

Alda P, Martorelli S (2014) Larval trematodes infecting the South-American intertidal mud snail Heleobia australis (Rissooidea: Cochliopidae). Acta Parasitol 59.

Alvarez MF, Esquius KS, Addino M, Alberti J, Iribarne O, Botto F (2013) Cascading top-down effects on estuarine intertidal meiofaunal and algal assemblages. J Exp Mar Biol Ecol 440:216224.

Angeletti S, Cervellini PM (2015) Population structure of the burrowing crab Neohelice granulata (Brachyura, Varunidae) in a southwestern Atlantic salt marsh. Lat Am J Aquat Res 43:539-547.

Angeletti S, Lescano L, Cervellini P (2014) Caracterización biosedimentológica y mineralógica de dos sectores intermareales del estuario de Bahía Blanca. GeoActa 39:54-67.

Appleton RD, Palmer AR (1988) Water-borne stimuli released by predatory crabs and damaged prey induce more predator-resistant shells in a marine gastropod. PNAS 85:4387-4391. 
1 Barutot RA, D'Incao F, Fonseca DB (2011) Natural diet of Neohelice granulata (Dana, 1851)

2 (Crustacea, Varunidae) in two salt marshes of the estuarine region of the Lagoa dos Patos

3 lagoon. Braz Arch Biol Technol 54:91-98.

4 Bates D, Mächler M, Bolker B, Walker S (2014) Fitting linear mixed-effects models using

5 lme4. J Stat Softw 67:1-48

6 Berrigan D, Scheiner S (2004) Modeling the evolution of phenotypic plasticity. In: Phenotypic

7 plasticity: Functional and conceptual approaches, DeWitt TJ, Scheiner, SM (eds). Oxford,

8 Univ. Press, New York, p 82-97

9 Bonel N, Lorda J (2015) Growth and body weight variability of the invasive mussel

10 Limnoperna fortunei (Mytilidae) across habitat and season. Malacologia 58:129-145.

11 Boulding EG, Hay TK (1993) Quantitative genetics of shell form of an intertidal snail:

12 constraints on short-term response to selection. Evolution 47:576.

13 Bourdeau PE (2011) Constitutive and inducible defensive traits in co $\square$ occurring marine snails

14 distributed across a vertical rocky intertidal gradient. Funct Ecol 25:177-185.

15 Bourdeau PE, Butlin RK, Brönmark C, Edgell TC, Hoverman JT, Hollander J (2015) What can

16 aquatic gastropods tell us about phenotypic plasticity? A review and meta-analysis. Heredity

$17 \quad 115: 312-321$.

18 Canepuccia AD, Escapa M, Daleo P, Alberti J, Botto F, Iribarne OO (2007) Positive

interactions of the smooth cordgrass Spartina alterniflora on the mud snail Heleobia australis, in South Western Atlantic salt marshes. J Exp Mar Biol Ecol 353:180-190.

Carcedo MC, Fiori SM (2012) Long-term study of the life cycle and growth of Heleobia australis (Caenogastropoda, Cochliopidae) in the Bahía Blanca estuary, Argentina. Ciencias Marinas 38:589-597.

24 Carvajal-Rodríguez A, Conde-Padín P, Rolán-Alvarez E (2005) Decomposing shell form into 25 size and shape by geometric morphometric methods in two sympatric ecotypes of Littorina 26 saxatilis. J Mollus Stud 71:313-318.

27 Chapman MG (1995) Spatial patterns of shell shape of three species of co-existing littorinid 28 snails in New South Wales, Australia. J Mollus Stud 61:141-162.

29 Chevin L-M, Lande R (2009) When do adaptive plasticity and genetic evolution prevent

30 extinction of a density-regulated population? Evolution 64:1143-1150.

31 Cole LC (1954) The population consequences of life history phenomena. Q Rev Biol 29:10332137.

33 Collier JL, Fitzgerald SP, Hice LA, Frisk MG, McElroy AE (2014) A new PCR-based method 34 shows that blue crabs (Callinectes sapidus (Rathbun)) consume winter flounder 35 (Pseudopleuronectes americanus (Walbaum)). PLoS ONE 9:e85101.

36 Conde-Padín P, Grahame JW, Rolán-Alvarez E (2007) Detecting shape differences in species of 37 the Littorina saxatilis complex by morphometric analysis. J Mollus Stud 73:147-154.

38 Curtis L (1987) Vertical distribution of an estuarine snail altered by a parasite. Science 39 235:1509-1511.

40 De Francesco CG, Isla FI (2003) Distribution and abundance of hydrobiid snails in a mixed 41 estuary and a coastal lagoon, Argentina. Estuaries 26:790-797. 
1 De Francesco CG, Isla FI (2004) The life cycle and growth of Heleobia australis (d'Orbigny,

2 1835) and H. conexa (Gaillard, 1974) (Gastropoda: Rissooidea) in Mar Chiquita coastal lagoon

3 (Argentina). J Mollus Stud 70:173-178.

4 De Jong G (2005) Evolution of phenotypic plasticity: patterns of plasticity and the emergence of

5 ecotypes: Research review. New Phytol 166:101-118.

6 De Jong G (1999) Unpredictable selection in a structured population leads to local genetic

7 differentiation in evolved reaction norms. J Evolution Biol 12:839-851.

8 Denny MW, Paine RT (1998) Celestial mechanics, sea-level changes, and intertidal ecology.

9 Biol Bull 194:108-115.

10 Dillon RT, Jacquemin SJ, Pyron M (2013) Cryptic phenotypic plasticity in populations of the

11 freshwater prosobranch snail, Pleurocera canaliculata. Hydrobiologia 709:117-127.

12 D’Incao F, Silva KG, Ruffino ML, Braga AC (1990) Hábito alimentar do caranguejo

13 Chasmagnathus granulata Dana, 1851 na barra do Rio Grande, RS (Decapoda, Grapsidae).

14 Atlântica 12:85-93.

15 Echeverría CA, Neves RAF, Pessoa LA, Paiva PC (2010) Spatial and temporal distribution of

16 the gastropod Heleobia australis in an eutrophic estuarine system suggests a metapopulation

17 dynamics. NS 02:860-867.

Elías R, Iribarne O, Bremec CS, Martinez DE (2004) Comunidades bentónicas de fondos blandos. In: Ecosistema del Estuario de Bahía Blanca, Piccolo M.C., Hoffmeyer M.S. EDIUNS

20 (UNS), Bahía Blanca, p 179-190

Fox J (2003) Effect displays in R for generalised linear models. J Stat Softw 8:1-27.

Fox J, Weisberg S, Adler D, Bates D, Baud-Bovy G, Ellison S, Heilberger R (2011) Package

"car": Companion to applied regression. R package version 2.0-11. https://socialsciences.mcmaster.ca/jfox/Books/Companion/

Fredensborg BL, Mouritsen KN, Poulin R (2005) Impact of trematodes on host survival and population density in the intertidal gastropod Zeacumantus subcarinatus. Mar Ecol Prog Ser 290:109-117.

Fredensborg BL, Mouritsen KN, Poulin R (2006) Relating bird host distribution and spatial heterogeneity in trematode infections in an intertidal snail-from small to large scale. Mar Biol 149:275-283.

Gaillard MC, Castellanos ZA (1976) Mollusca Gasteropoda Hydrobiidae. In: Fauna de agua dulce de la República Argentina, Ringuelet R. A. FECIC, Buenos Aires, p 1-40

Ghalambor CK, McKay JK, Carroll SP, Reznick DN (2007) Adaptive versus non-adaptive ecotypes of the dogwhelk Nucella lapillus. Evol Ecol 23:261-280.

39 Hays CG (2007) Adaptative phenotypic differentiation across the intertidal gradient in the alga $40 \quad$ Silvetia compressa. Ecology 88:149-157.

41 Hershler R, Thompson F (1992) A review of the aquatic gastropod subfamily Cochliopinae 
1 (Prosobranchia, Hydrobiidae). Malacological Review 5.

2 Hill JK, Griffiths HM, Thomas CD (2011) Climate change and evolutionary adaptations at

3 species' range margins. Annu Rev Entomol 56:143-159.

4 Hoffmann AA, Sgrò CM (2011) Climate change and evolutionary adaptation. Nature 470:479-

5485.

6 Hollander J, Collyer ML, Adams DC, Johannesson K (2006) Phenotypic plasticity in two

7 marine snails: constraints superseding life history. J Evolution Biol 19:1861-1872.

8 Hollander J, Smadja CM, Butlin RK, Reid DG (2013) Genital divergence in sympatric sister

9 snails. J Evol Biol 26:210-215.

10 Ieno E, Alemany D, Blanco DE, Bastida R (2004) Prey size selection by Red Knot feeding on

11 mud snails at Punta Rasa (Argentina) during migration. Waterbirds 27:493-498.

12 Janzen DH, Burns JM, Cong Q, Hallwachs W, Dapkey T, Manjunath R, Hajibabaei M, Hebert

13 PDN, Grishin NV (2017) Nuclear genomes distinguish cryptic species suggested by their DNA

14 barcodes and ecology. Proc Natl Acad Sci USA 114:8313-8318.

15 Johannesson B, Johannesson K (1996) Population differences in behaviour and morphology in

16 the snail Littorina saxatilis: phenotypic plasticity or genetic differentiation? J Zool 240:475-

17493.

18 Johannesson K (2003) Evolution in Littorina: ecology matters. J Sea Res 49:107-117.

19 Johnson MS, Watts RJ, Black R (1994) High levels of genetic subdivision in peripherally

20 isolated populations of the atherinid fish Craterocephalus capreoli in the Houtman Abrolhos

21 Islands, Western Australia. Marine Biology 119:179-184.

22 Kameda Y, Kawakita A, Kato M (2009) Reproductive character displacement in genital 23 morphology in Satsuma land snails. Am Nat 173:689-697.

24 Kemp P, Bertness MD (1984) Snail shape and growth rates: Evidence for plastic shell allometry 25 in Littorina littorea. PNAS 81:811-813.

26 Kemppainen P, Panova M, Hollander J, Johannesson K (2009) Complete lack of mitochondrial

27 divergence between two species of NE Atlantic marine intertidal gastropods. J Evolution Biol

28 22:2000-2011.

29 Komsta L (2011) Outliers: Tests for outliers. R package version 0.13. http://www.komsta.net

30 Kuris AM (1974) Trophic interactions: similarity of parasitic castrators to parasitoids. Q Rev

31 Biol 49:129-148.

32 Lafferty KD (1993) The marine snail, Cerithidea californica, matures at smaller sizes where

33 parasitism is high. Oikos 68:3.

34 Lafferty KD, Sammond DT, Kuris AM (1994) Analysis of larval trematode communities.

35 Ecology 75:2275.

36 Larsson J, Westram AM, Bengmark S, Lundh T, Butlin RK (2020) A developmentally

37 descriptive method for quantifying shape in gastropod shells. J R Soc Interface 17:20190721.

38 Levin LA, Ziebis W, Mendoza GF, Growney-Cannon V, Walther S (2006) Recruitment

39 response of methane-seep macrofauna to sulfide-rich sediments: An in situ experiment. J Exp 
Mar Biol Ecol 330:132-150.

2 Levins R (1968) Evolution in changing environments: some theoretical explorations. No. 2.

3 Princeton University Press.

4 Levri EP, Dillard J, Martin T (2005) Trematode infection correlates with shell shape and

5 defence morphology in a freshwater snail. Parasitology 130:699-708.

6 Lewontin RC (1965) Selection for colonizing ability. In: Proceedings of the First International

7 Union of Biological Sciences Symposia on General Biol. Academic Press, p 77-94

8 Liu H-P, Hershler R, Thompson FG (2001) Phylogenetic relationships of the Cochliopinae

9 (Rissooidea: Hydrobiidae): an enigmatic group of aquatic gastropods. Mol Phylogenet Evol $10 \quad 21: 17-25$.

11 Machin J (1967) Structural adaptation for reducing water $\square$ loss in three species of terrestrial 12 snail. J Zool 152:55-65.

13 Marshall DJ, Monro K, Bode M, Keough MJ, Swearer S (2010) Phenotype-environment mismatches reduce connectivity in the sea. Ecol Lett 13:128-140.

Martorelli SR (1991) El ciclo biológico abreviado de Microphallus simillimus (Travassos, 1920), comb. n. (Digenea; Microphallidae) parásito de Heleobia conexa (Mollusca, Hydrobiidae) y de Himantopus melanurus (Aves; Recurvirostridae) en Argentina. Iheringia Ser Zool 71:91-98.

Mather K (1955) Polymorphism as an outcome of disruptive selection. Evolution 9:52-61. (Lepidoptera: Nymphalidae): reconciling classical taxonomy with the multispecies coalescent. Syst Entomol 44:745-756.

Meerhoff EI, Rodríguez-Gallego LR, Claramunt S (2013) Dieta de ocho especies de aves costeras en la barra de laguna de Rocha, Uruguay. Boletín de la Sociedad Zoológica del 25 Uruguay 22:12-22. acidification and elevated temperature on shell plasticity and its energetic basis in an intertidal gastropod. Mar Ecol Prog Ser 472:155-168.

Milroy S (2015) Field methods in marine science: from measurements to models. Garland 30 Science. and may create a new ecological niche for snail hosts. Proc R Soc B 273:1323-1328. growth, fecundity, egestion and locomotion in Hydrobia ulvae (Pennant)(Gastropoda: Prosobranchia). J Exp Mar Biol Ecol 181:53-66. tipping point: global warming and parasitism combine to alter community structure and function. Glob Change Biol 24:4340-4356.

39 Neves RAF, Valentin JL, Figueiredo GM (2010) Morphological description of the gastropod 40 Heleobia australis (Hydrobiidae) from egg to hatching. Braz j oceanogr 58:247-250. 
1 Palmer AR (1981) Do carbonate skeletons limit the rate of body growth? Nature 292:150-152.

2 Palmer AR (1990) Effect of crab effluent and scent of damaged conspecifics on feeding,

3 growth, and shell morphology of the Atlantic dogwhelk Nucella lapillus (L.). Hydrobiologia

4 193:155-182.

5 Parsons KE (1997) Role of dispersal ability in the phenotypic differentiation and plasticity of

6 two marine gastropods. Oecologia 110:461-471.

7 Perillo GME, Piccolo MC, Parodi E, Freije RH (2001) The Bahia Blanca Estuary, Argentina. In:

8 Coastal Marine Ecosystems of Latin America. Seeliger U, Kjerfve B (eds) Springer Berlin

9 Heidelberg, Berlin, Heidelberg, p 205-217

10 Petracci PF, Delhey K (2005) Guía de aves costeras y marinas de la ría de Bahía Blanca. Harris

11 y Cía S.R.L., Bahía Blanca.

12 Piccolo MC, Hoffmeyer MS (2004) El ecosistema del estuario de Bahía Blanca. Instituto

13 Argentino de Oceanografía, Bahía Blanca, Argentina. Sapiensa., Bahía Blanca.

14 Pigliucci M, Murren CJ, Schlichting CD (2006) Phenotypic plasticity and evolution by genetic

15 assimilation. J Exp Biol 209:2362-2367.

16 Pinheiro J, Bates D, DebRoy S, Sarkar D, R Core Team (2017) Nlme: linear and nonlinear

17 mixed effects models. R package version 3.1-131. https://cran.r-

18 project.org/web/packages/nlme/index.html

19 Pointier J, Noya O, Amarista M, Théron A (2004) Lymnaea cousini Jousseaume, 1887

20 (Gastropoda: Lymnaeidae): first record for Venezuela. Mem Inst Oswaldo Cruz 99:567-569.

21 Poulin R, Thomas F (1999) Phenotypic variabilityinduced by parasites. Parasitol Today 15:28-

2232.

23 Pratolongo P, Kirby J, Plater A, Brinson M (2009) Temperate coastal wetlands: morphology,

24 sediment processes, and plant communities. In: An Integrated Ecosystem Approach, Coastal

25 Wetlands, Perillo, G.M.E., Wolanski, E., Cahoon, D.R., Brinson, M.M. (Eds.). Elsevier,

26 Amsterdam, p 185-210

27 Pratolongo P, Perillo GME, Piccolo MC (2010) Combined effects of waves and plants on a mud

28 deposition event at a mudflat-saltmarsh edge in the Bahía Blanca estuary. Estuar Coast Shelf Sci

$29 \quad 87: 207-212$.

30 Price TD, Qvarnström A, Irwin DE (2003) The role of phenotypic plasticity in driving genetic

31 evolution. Proc R Soc Lond B 270:1433-1440.

32 Probst S, Kube J (1999) Histopathological effects of larval trematode infections in mudsnails

33 and their impact on host growth: what causes gigantism in Hydrobia ventrosa (Gastropoda:

34 Prosobranchia)? J Exp Mar Biol Ecol 238:49-68.

35 Puillandre N, Lambert A, Brouillet S, Achaz G (2012) ABGD, Automatic Barcode Gap

36 Discovery for primary species delimitation: ABGD, automatic barcode gap discovery. Mol Ecol

$37 \quad 21: 1864-1877$.

38 Revelle W (2018) Psych: Procedures for Personality and Psychological Research. R package

39 version 1.8.10. https://personality-project.org/r/psych/

40 Ripley B, Venables B, Bates DM, Hornik K, Gebhardt A, Firth D, Ripley MB (2013) Package

41 'mass.' R package version 7.3-23. http://www.stats.ox.ac.uk/pub/MASS4/ 
1 Roff DA (1992) The evolution of life histories: theory and analysis. Chapman \& Hall, New

2 York.

3 Rolán-Alvarez E (2007) Sympatric speciation as a by-product of ecological adaptation in the

4 Galician Littorina saxatilis hybrid zone. J Mollus Stud 73:1-10.

5 Sanford E, Kelly MW (2011) Local adaptation in marine invertebrates. Annu Rev Mar Sci

$6 \quad 3: 509-535$.

7 Scheiner SM (1998) The genetics of phenotypic plasticity. VII. Evolution in a spatially-

8 structured environment. J Evol Biol 11:303-320.

9 Schweizer M, Triebskorn R, Köhler H (2019) Snails in the sun: Strategies of terrestrial

10 gastropods to cope with hot and dry conditions. Ecol Evol 9:12940-12960.

11 Smith NF (2001) Spatial heterogeneity in recruitment of larval trematodes to snail intermediate

12 hosts. Oecologia 127:115-122.

13 Spivak E, Anger K, Luppi T, Bas C, Ismael D (1994) Distribution and habitat preferences of

14 two grapsid crab species in Mar Chiquita Lagoon (Province of Buenos Aires, Argentina).

15 Helgol Meeresunters 48:59-78.

16 Struhsaker JW (1968) Selection mechanisms associated with intraspecific shell variation in

17 Littorina picta (Prosobranchia: Mesogastropoda). Evolution 22:459-480.

18 Travis J (1994) Evaluating the adaptive role of morphological plasticity. In: Ecological

19 Morphology: Integrative Organismal Biology, eds P.C. Wainwright\&S.M. Reilly. University of

20 Chicago Press, Chicago, p 99-122

21 Trussell GC (2000a) Phenotypic clines, plasticity, and morphological trade $\square$ offs in an intertidal 22 snail. Evolution 54:151-166.

23 Trussell GC (2000b) Predator-induced plasticity and morphological trade-offs in latitudinally

24 separated populations of Littorina obtusata. Evol Ecol Res 2:803-822.

25 Vermeij GJ (1972) Intraspecific shore-level size gradients in intertidal molluscs. Ecology

$26 \quad 53: 693-700$.

27 Vermeij GJ (1973) Morphological patterns in high-intertidal gastropods: Adaptive strategies

28 and their limitations. Mar Biol 20:319-346.

29 Via S, Lande R (1985) Genotype-environment interaction and the evolution of phenotypic

30 plasticity. Evolution 39:505.

31 Vu VQ (2011) Ggbiplot: A ggplot2 based biplot. R package version 0.55.

32 https://www.rdocumentation.org/packages/ggbiplot/versions/0.55

33 Waddington CH (1953) Genetic assimilation of an acquired character. Evolution 7:118-126.

34 West-Eberhard MJ (2003) Developmental plasticity and evolution. Oxford University Press, 35 Oxford; New York.

36 West-Eberhard MJ (1989) Phenotypic plasticity and the origins of diversity. Annu Rev Ecol

37 Evol Syst 2:249-278.

38 Westram AM, Faria R, Johannesson K, Butlin R (2021) Using replicate hybrid zones to

39 understand the genomic basis of adaptive divergence. Mol Ecol: 10.1111/mec.15861. 
1 Wickham H (2011) The split-apply-combine strategy for data analysis. J Stat Softw 40:1-29.

2 Wickham H, Chang W (2008) Ggplot2: an implementation of the grammar of graphics. R

3 package version 0.8 . https://ggplot2.tidyverse.org

4 Wickham H, François R, Henry L, Müller K (2019a) Dplyr: a grammar of data manipulation. R 5 package version 0.8. 0.1. https://cran.r-project.org/web/packages/dplyr/index.htmlc

6 Wickham H, Hester J, Chang W (2019b) Devtools: tools to make developing R packages easier.

7 R package version 2.2.1. https://devtools.r-lib.org

8 Zuur AF (ed) (2009) Mixed effects models and extensions in ecology with R. Springer, New 9 York, NY.

10 


\section{Tables}

12 Table 1. Summary of means $( \pm \mathrm{SE})$ and statistical significance of the two-way ANOVA testing for habitat and seasonal effect on total snail density samples are indicated between parentheses. Value in bold indicates overall mean. We reported raw estimates whereas the model fits for Ln-transformed density. See Methods section for details.

16

\begin{tabular}{|c|c|c|c|c|c|c|c|c|c|c|c|}
\hline \multirow[t]{2}{*}{ Variable } & \multirow[t]{2}{*}{ Seasons } & \multicolumn{3}{|r|}{ Habitats } & \multirow{2}{*}{$\begin{array}{r}\text { Mean by } \\
\text { Season }\end{array}$} & \multirow[t]{2}{*}{ Habitat effect } & \multirow{2}{*}{\multicolumn{2}{|c|}{$\begin{array}{l}\text { Habitat Effect size } \\
\text { comparison }\end{array}$}} & \multirow[t]{2}{*}{ Season effect } & \multirow{2}{*}{$\begin{array}{r}\text { Season } \\
\text { comparison }\end{array}$} & \multirow{2}{*}{$\begin{array}{r}\text { Effec } \\
\text { size }\end{array}$} \\
\hline & & Flats $(F)$ & Marshes (M) & Pans (P) & & & & & & & \\
\hline \multirow[t]{6}{*}{ Total density } & Summer (Su) & $132 \pm 17(9)$ & $52 \pm 14(9)$ & $128 \pm 20(9)$ & $104 \pm 12(27)$ & $F_{(2,106)}=15.48^{\star \star \star}$ & P vs.M & $5.49^{\star \star \star}$ & $F_{(3,106)}=6.22^{* \star *}$ & Au vs.Sp & $4.26^{\star \star \star}$ \\
\hline & Autumn (Au) & $65 \pm 13(9)$ & $87 \pm 42(9)$ & $70 \pm 14(9)$ & $74 \pm 15(27)$ & & $\mathrm{M} v s . \mathrm{F}$ & $-3.54^{* * *}$ & & Wi vs.Sp & $2.69^{*}$ \\
\hline & Winter (Wi) & $92 \pm 20(8)$ & $70 \pm 24(9)$ & $206 \pm 30(9)$ & $124 \pm 18(26)$ & & $\mathrm{P}$ vs. F & 1.91 & & Su vs.Sp & $2.57^{*}$ \\
\hline & Spring (Sp) & $187 \pm 36(9)$ & $114 \pm 36(9)$ & $317 \pm 34(9)$ & $206 \pm 26(27)$ & & & & & Su vs.Au & 1.68 \\
\hline & & & & & & & & & & Au vs.Wi & 1.53 \\
\hline & Mean by Habitat & $120 \pm 14(35)$ & $81 \pm 15(36)$ & $180 \pm 20(36)$ & $127 \pm 10(107)$ & & & & & Su vs.Wi & 0.14 \\
\hline
\end{tabular}

$* P<0.05 ; * * P<0.01 ; * * * P<0.001$. We applied the Holm-Bonferroni correction for multiple testing when comparing effect sizes. 
Table 2. Uninfected adult snails. Summary of means $( \pm$ SE) and statistical significance of habitat and sex effect on shell and aperture morphometrics of uninfected adult individuals of the mud snail Heleobia australis from the intertidal area of the Bahía Blanca estuary, Argentina. Variables are the same

21 as indicated in table 2. Number of observations are indicated between parentheses, which are only shown for shell size but are the same for other traits 22 measured.

\begin{tabular}{|c|c|c|c|c|c|c|c|c|c|c|}
\hline $\begin{array}{l}\text { Traits } \\
\text { measured }\end{array}$ & Habitat type & Males $(\delta)$ & $\begin{array}{r}\text { Sex } \\
\text { Females () }\end{array}$ & Sex pooled & Habitat effect & $\begin{array}{r}\text { Habitat } \\
\text { comparison }\end{array}$ & $\begin{array}{c}\text { Effect } \\
\text { size }\end{array}$ & Sex effect & \multirow[t]{2}{*}{$\begin{array}{r}\text { Sex } \\
\text { comparison }\end{array}$} & \multirow[t]{2}{*}{$\begin{array}{r}\text { Effect } \\
\text { size }\end{array}$} \\
\hline \multirow{5}{*}{$\begin{array}{l}\text { Shell size } \\
\Phi\end{array}$} & Flats (F) & $6.19 \pm 0.18(388)$ & $6.17 \pm 0.18(396)$ & $6.17 \pm 0.16(784)$ & Males & $\mathrm{P} v s . \mathrm{F}$ & $17.91^{\star \star \star}$ & Flats & & \\
\hline & Marshes (M) & $6.78 \pm 0.13(266)$ & $6.64 \pm 0.11(245)$ & $6.71 \pm 0.11(511)$ & $X_{2}^{2}=346.22^{\star \star \star}$ & P vs.M & $11.01^{* \star *}$ & $X_{1}^{2}=0.20 ;$ n.s. & ovs.우 & 0.50 \\
\hline & Pans (P) & $7.97 \pm 0.36(600)$ & $7.55 \pm 0.40(738)$ & $7.74 \pm 0.40$ (1338) & & $M v s . F$ & $4.08^{\star \star \star}$ & Marshes & & \\
\hline & Habitats pooled & $7.14 \pm 0.22(1254)$ & $6.95 \pm 0.25$ (1379) & & $\begin{array}{l}\text { Females } \\
X_{2}^{2}=249.33^{\star * *}\end{array}$ & $\begin{array}{l}\mathrm{P} \text { vs. } \mathrm{F} \\
\mathrm{P} \text { vs. M }\end{array}$ & $\begin{array}{c}15.20^{\star * *} \\
9.01^{\star * *}\end{array}$ & $\begin{array}{l}X_{1}^{2}=1.57 ; \text { n.s. } \\
\text { Pans }\end{array}$ & ovs.우 & 1.25 \\
\hline & & & & & & $M v s . F$ & $3.62^{\star \star \star}$ & $X_{1}^{2}=24.30^{\star * *}$ & Jvs.우 & $4.93^{\star * *}$ \\
\hline \multirow{4}{*}{$\begin{array}{l}\text { Shell } \\
\text { shape } \dagger\end{array}$} & Flats & $2.27 \pm 0.02$ & $2.26 \pm 0.02$ & $2.27 \pm 0.02$ & $X_{2}^{2}=101.02^{\star \star \star}$ & $\mathrm{P} v s . \mathrm{F}$ & $10.13^{\star \star \star}$ & $X_{1}^{2}=29.02^{\star \star \star}$ & ovs.우 & $5.39^{* * *}$ \\
\hline & Marshes & $2.32 \pm 0.01$ & $2.29 \pm 0.01$ & $2.31 \pm 0.01$ & & P vs.M & $5.31^{* * *}$ & & & \\
\hline & Pans & $2.35 \pm 0.01$ & $2.31 \pm 0.01$ & $2.33 \pm 0.01$ & & $\mathrm{M} v s . \mathrm{F}$ & $3.61^{* * *}$ & & & \\
\hline & Habitats pooled & $2.32 \pm 0.01$ & $2.29 \pm 0.01$ & & & & & & & \\
\hline \multirow{4}{*}{$\begin{array}{l}\text { Aperture } \\
\text { size }\end{array}$} & Flats & $1.82 \pm 0.05$ & $1.83 \pm 0.06$ & $1.82 \pm 0.05$ & $X_{2}^{2}=362.62^{\star \star *}$ & $\mathrm{P}$ vs. F & $17.10^{* \star *}$ & $X_{1}^{2}=8.54^{\star \star}$ & ठvs.우 & $2.93^{* *}$ \\
\hline & Marshes & $1.90 \pm 0.04$ & $1.86 \pm 0.03$ & $1.88 \pm 0.03$ & & P vs.M & $12.79^{\star * *}$ & & & \\
\hline & Pans & $2.10 \pm 0.09$ & $2.05 \pm 0.10$ & $2.07 \pm 0.09$ & & $M v s . F$ & 1.63 & & & \\
\hline & Habitats pooled & $1.97 \pm 0.06$ & $1.94 \pm 0.07$ & & & & & & & \\
\hline \multirow{4}{*}{$\begin{array}{l}\text { Aperture } \\
\text { shape }\end{array}$} & Flats & $1.73 \pm 0.03$ & $1.73 \pm 0.03$ & $1.73 \pm 0.03$ & $X_{2}^{2}=535.73^{\star * *}$ & $\mathrm{P}$ vs. F & $-22.91^{\star * *}$ & $X_{1}^{2}=0.04 ;$ n.s. & ठvs.우 & -0.20 \\
\hline & Marshes & $1.70 \pm 0.02$ & $1.71 \pm 0.01$ & $1.70 \pm 0.02$ & & P vs.M & $-15.35^{\star * *}$ & & & \\
\hline & Pans & $1.60 \pm 0.02$ & $1.60 \pm 0.02$ & $1.60 \pm 0.02$ & & M vs. F & $-3.86^{\star \star \star}$ & & & \\
\hline & Habitats pooled & $1.66 \pm 0.02$ & $1.66 \pm 0.03$ & & & & & & & \\
\hline
\end{tabular}

$\Phi$ As there was a significant interaction between Habitat and Sex when testing shell size, we report effect sizes separately for this trait.

$\dagger$ We report estimates of shell shape corrected for shell size, as the pattern observed was not the same when removing the covariate from the model.

$* P<0.05 ; * * P<0.01 ; * * * P<0.001$. We applied the Holm-Bonferroni correction for multiple testing when comparing effect sizes. 
Table 3. Infected vs. Uninfected adult snails. Summary of means ( \pm SE) and statistical significance of status (infected of uninfected) and sex effect on shell and aperture morphometrics of the intertidal mud snail Heleobia australis from the Bahía Blanca estuary, Argentina. In these analyses we only considered individuals from pans, which allowed for preventing habitat effect on morphometry. Shell size estimated as the volume of a cone (mm ${ }^{3}$ ), shell shape as the length to width ratio (SL/SW), aperture size as the area of an ellipse $\left(\mathrm{mm}^{2}\right)$, and aperture shape as the ratio between aperture length and width (AL/AW). Number of observations are indicated between parentheses, which are only shown for shell size but are the same for other traits measured.

\begin{tabular}{|c|c|c|c|c|c|c|c|c|c|c|}
\hline $\begin{array}{l}\text { Traits } \\
\text { measured }\end{array}$ & Habitat type & Male $(\hat{\partial})$ & $\begin{array}{r}\text { Sex } \\
\text { Female }(+)\end{array}$ & Sex pooled & Status effect & $\begin{array}{r}\text { Status } \\
\text { comparison }\end{array}$ & Effect size & Sex Effect & $\begin{array}{r}\text { Sex } \\
\text { comparison }\end{array}$ & $\begin{array}{r}\text { Effect } \\
\text { size }\end{array}$ \\
\hline \multirow[t]{3}{*}{ Shell size } & Uninfected (U) & $7.97 \pm 0.36(600)$ & $7.55 \pm 0.40(738)$ & $7.74 \pm 0.38(1338)$ & $X_{1}^{2}=149.69^{\star \star \star}$ & U vs.I & $12.42^{* * *}$ & $X_{1}^{2}=31.68^{\star \star \star}$ & ovs.우 & $5.65^{\star * *}$ \\
\hline & Infected (I) & $7.01 \pm 0.14(432)$ & $6.76 \pm 0.20(573)$ & $6.86 \pm 0.16(1005)$ & & & & & & \\
\hline & Status pooled & $7.59 \pm 0.28(1032)$ & $7.22 \pm 0.32(1311)$ & & & & & & & \\
\hline \multirow{5}{*}{$\begin{array}{l}\text { Shell shape } \\
\Phi\end{array}$} & Uninfected & $2.36 \pm 0.01$ & $2.32 \pm 0.01$ & $2.34 \pm 0.01$ & Males & & & Uninfected & & \\
\hline & Infected & $2.40 \pm 0.01$ & $2.39 \pm 0.02$ & $2.40 \pm 0.01$ & $X_{1}^{2}=11.82^{\star \star \star}$ & U vs.I & $3.43^{\star * *}$ & $X_{1}^{2}=37.51^{\star \star *}$ & ठvs.무 & $6.12^{\star * *}$ \\
\hline & Status pooled & $2.38 \pm 0.01$ & $2.35 \pm 0.01$ & & & & & & & \\
\hline & & & & & Females & & & Infected & & \\
\hline & & & & & $X_{1}^{2}=99.50^{\star * *}$ & U vs.I & $9.98^{\star \star \star}$ & $X_{1}^{2}=0.09 ;$ n.s. & ovs. 우 & -0.30 \\
\hline \multirow[t]{3}{*}{ Aperture size } & Uninfected & $2.10 \pm 0.09$ & $2.05 \pm 0.10$ & $2.07 \pm 0.09$ & $X_{1}^{2}=408.65^{\star \star \star}$ & U vs.I & $21.11^{\star \star *}$ & $X_{1}^{2}=14.95^{\star \star \star}$ & ठvs.우 & $3.88^{\star \star \star}$ \\
\hline & Infected & $1.80 \pm 0.04$ & $1.76 \pm 0.06$ & $1.77 \pm 0.05$ & & & & & & \\
\hline & Status pooled & $1.98 \pm 0.07$ & $1.92 \pm 0.08$ & & & & & & & \\
\hline \multirow{3}{*}{$\begin{array}{l}\text { Aperture } \\
\text { shape }\end{array}$} & Uninfected & $1.60 \pm 0.02$ & $1.60 \pm 0.02$ & $1.60 \pm 0.02$ & $X_{1}^{2}=60.57^{\star \star \star}$ & U vs.I & $7.83^{\star *}$ & $X^{2}{ }_{1}=1.3 e-3 ;$ n.s. & ovs.早 & 0.03 \\
\hline & Infected & $1.56 \pm 0.02$ & $1.56 \pm 0.02$ & $1.56 \pm 0.02$ & & & & & & \\
\hline & Status pooled & $1.58 \pm 0.02$ & $1.58 \pm 0.02$ & & & & & & & \\
\hline
\end{tabular}

$\Phi$ As there was a significant interaction between Status and Sex when testing shell shape, we report effect sizes separately for this trait. $* P<0.05 ; * * P<0.01 ; * * * P<0.001$. We applied the Holm-Bonferroni correction for multiple testing when comparing effect size 


\section{Figure Captions}

38 Figure 1. Contrasting habitat conditions at the intertidal zone of the Bahía Blanca

39 estuary (Villa del Mar), Argentina. Three distinct habitats can be characterized: flats,

40 marshes, and pans. Flats and marshes are located in the upper zone and they drain at low

41 tide, though flats are free of vegetation and marshes covered by cordgrass (Spartina

42 alterniflora). Pans are free of vegetation but remain covered by water during low tide

43 and are located close the seaward edge. Thermal, saline, and dehydration stress are

44 strong selective forces occurring mainly in the upper intertidal area (flats and marshes)

45 whereas these inducing agents are weaker in pans, which exhibit low environmental

46 stress condition. Biotic agents also vary along the vertical distribution of the intertidal

47 zone. Predation risk is higher in the upper area (marshes) mainly driven by the grapsid

48 burrowing crab Neohelice granulata, which is commonly found in high abundances in

49 marshes, though it uses the entire intertidal zone. Parasite pressure also differs along the

50 intertidal zone. The prevalence (percentage of individuals infected) of trematodes is

51 higher in the lower area of the intertidal zone (pans), where parasite infection is

52 predominately caused by one extremely prevalent trematode, Microphallus simillimus.

54 Figure 2. Variation in total density (juveniles and adults pooled) of the planktotrophic

55 snail Heleobia australis across habitats and seasons in the intertidal area of the Bahía

56 Blanca estuary, Argentina. Bars represent \pm 1 SE.

58 Figure 3. Phenotypic variation in shell and aperture morphometrics of uninfected adult

59 snails Heleobia australis (cat. $i$ ) in the Bahía Blanca estuary, Argentina. Blue and red

60 dots indicate mean values of each variable and sex in each habitat (flats, marshes, and

61 pans). Mean values of shell shape were statistically corrected for shell size. Bars

62 represent $\pm 1 \mathrm{SE}$.

64 Figure 4. Phenotypic variation in shell and aperture morphometrics of infected and

65 uninfected adult snails Heleobia australis (cat. $i v$ ) in response to a strong parasite

66 pressure from a habitat with low environmental stress conditions but high parasite

67 prevalence (pans) in the Bahía Blanca estuary, Argentina. Blue and red dots indicate

68 mean values of each variable and sex (males and females, respectively). Mean values of

69 aperture size were statistically corrected for shell size. Bars represent \pm 1 SE. 
71 Figure 5. Shell weight (as proxy of thickness) and body mass variation of the intertidal

72 mud snail Heleobia australis across habitats with different biotic and abiotic selective

73 pressures in the Bahía Blanca estuary, Argentina. Bars represent $\pm 1 \mathrm{SE}$.

75 Figure 6. Differences in penis size $\left(\mathrm{mm}^{2}\right)$ of uninfected adult snails Heleobia australis

76 collected from three environmentally distinct habitats from the Bahía Blanca estuary,

77 Argentina and kept in standard laboratory conditions for 21 months, which ensured that

78 individuals analyzed were all adults. Bars represent $\pm 1 \mathrm{SE}$.

80 Figure 7. Summary of the responses observed in snail population density, shell and

81 aperture morphometrics, and shell and body weight of the intertidal mud snail Heleobia

82 australis from the Bahía Blanca estuary, Argentina. Such responses were induced by: (i)

83 Environmental pressure, whereby snails experiencing prolonged emersion times in

84 habitats that remain exposed to hot and dry conditions during low tide (marhses and

85 flats) exhibited lower density and lower mean values of morphological traits relative to

86 those from less environmental stress conditions (pans), which showed opposite

87 phenotypic responses; (ii) predation pressure caused by the presence of the burrowing

88 crab Neohelice granulata could be linked to the remarkable low density in marshes and

89 could have favored the expression of shell defenses as shell thickening, increased shell

90 globosity (lower SL to SW ratio), narrower apertures (higher AL to AW ratio); and (iii)

91 strong parasite pressure caused by Microphallus simillimus where morphological traits

92 of infected (I) snails shifted to lower mean values compared to uninfected (U) ones;

93 note that phenotypic differences are only shown for pans, where parasite prevalence was

94 the highest. Responses observed in this study are indicated by color-filled boxes, white-

95 filled boxes indicate possible mechanisms or processes that might explain the observed

96 responses. Green color refers to responses induced by environmental pressure, orange to

97 phenotypic variation induced by crab predation, and pink by parasite pressure. Upper

98 arrows $(\uparrow)$ indicate increase/higher/longer and down arrows $(\downarrow)$ indicate

99 decrease/lower/shorter. 

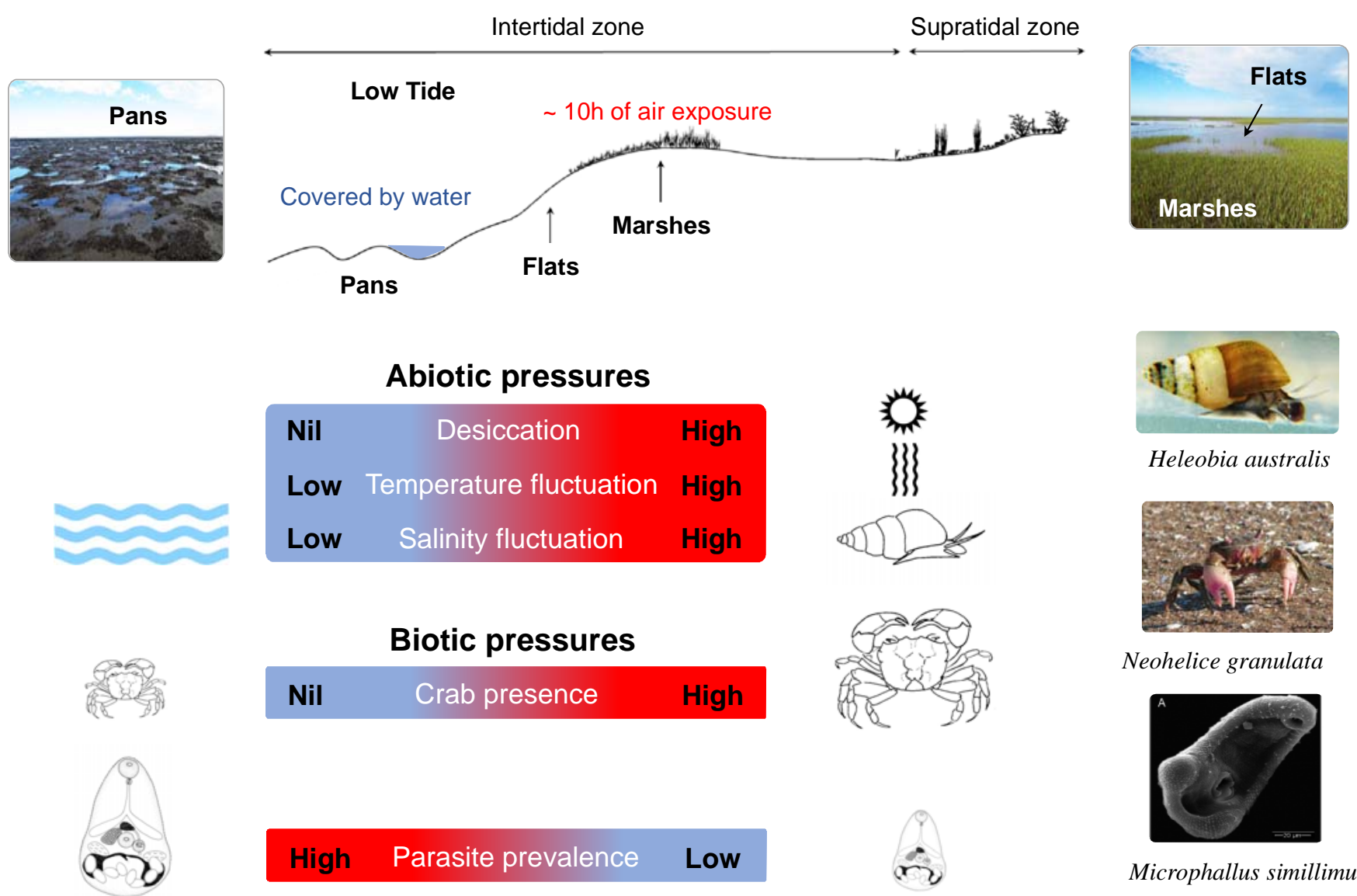

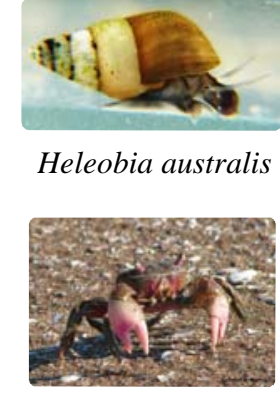

Neohelice granulata

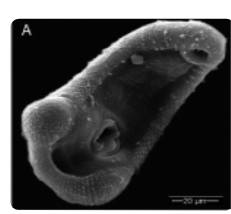

Microphallus simillimus

102 Figure 1. 

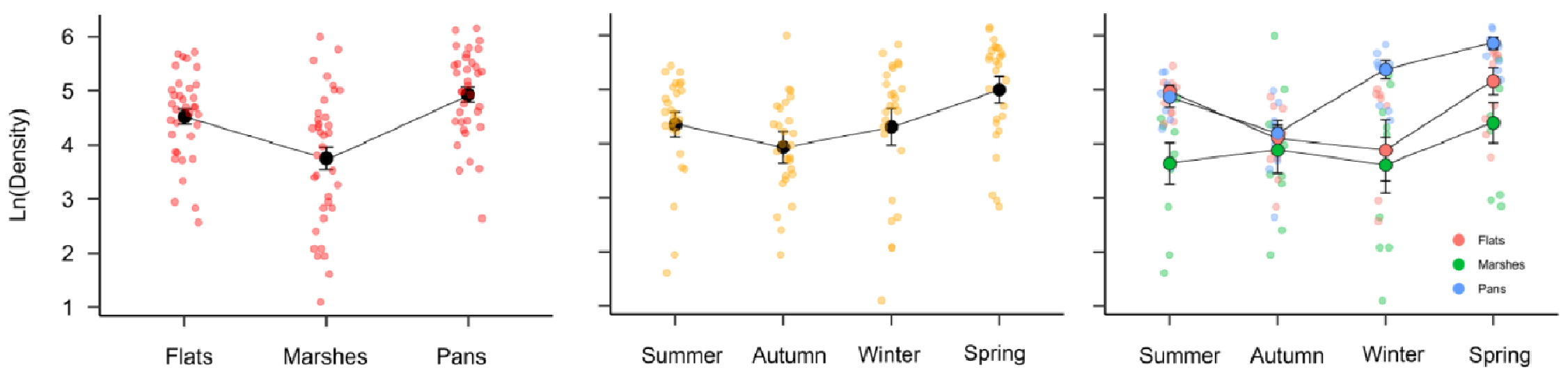

104 Figure 2. 

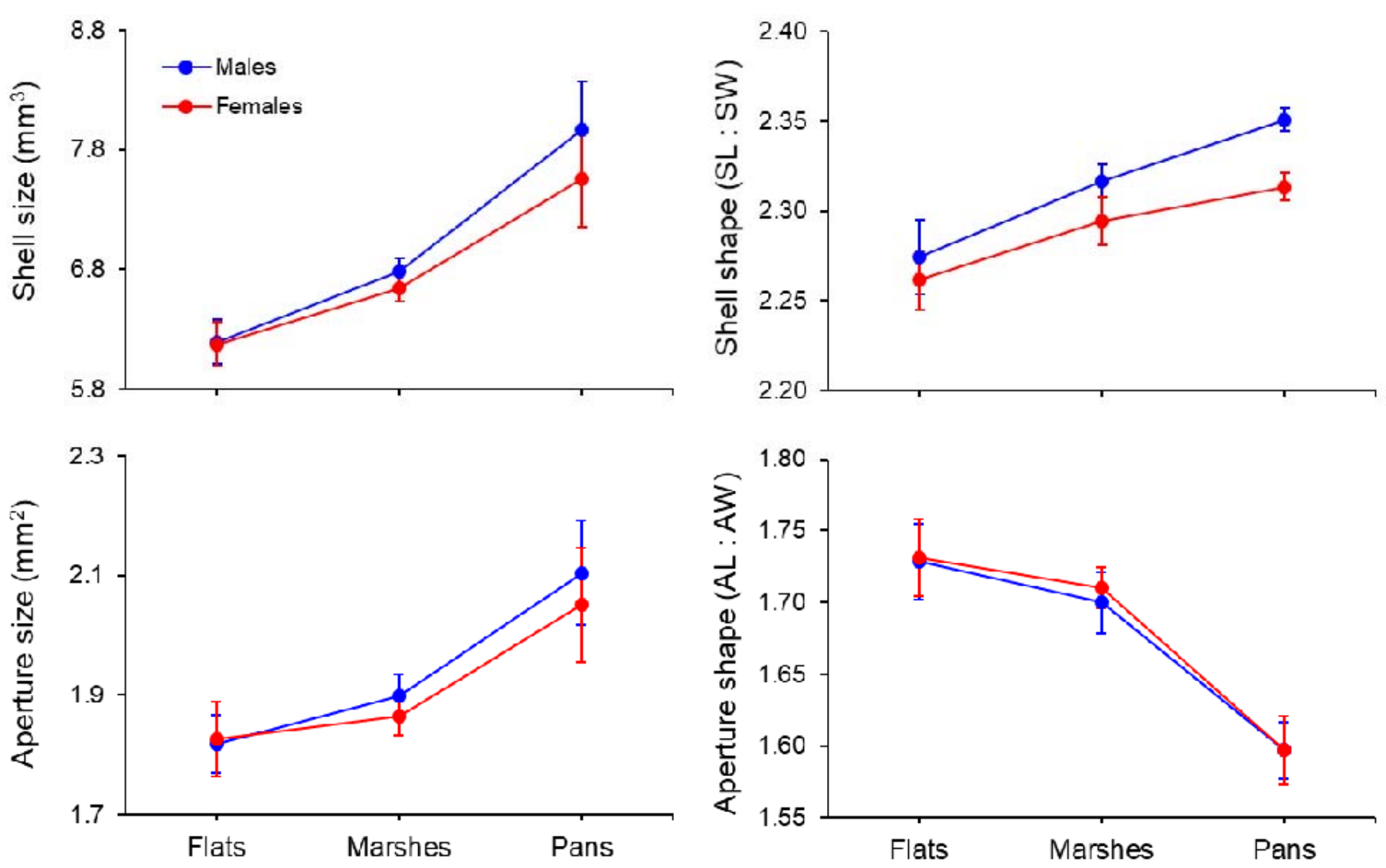

Figure 3. 

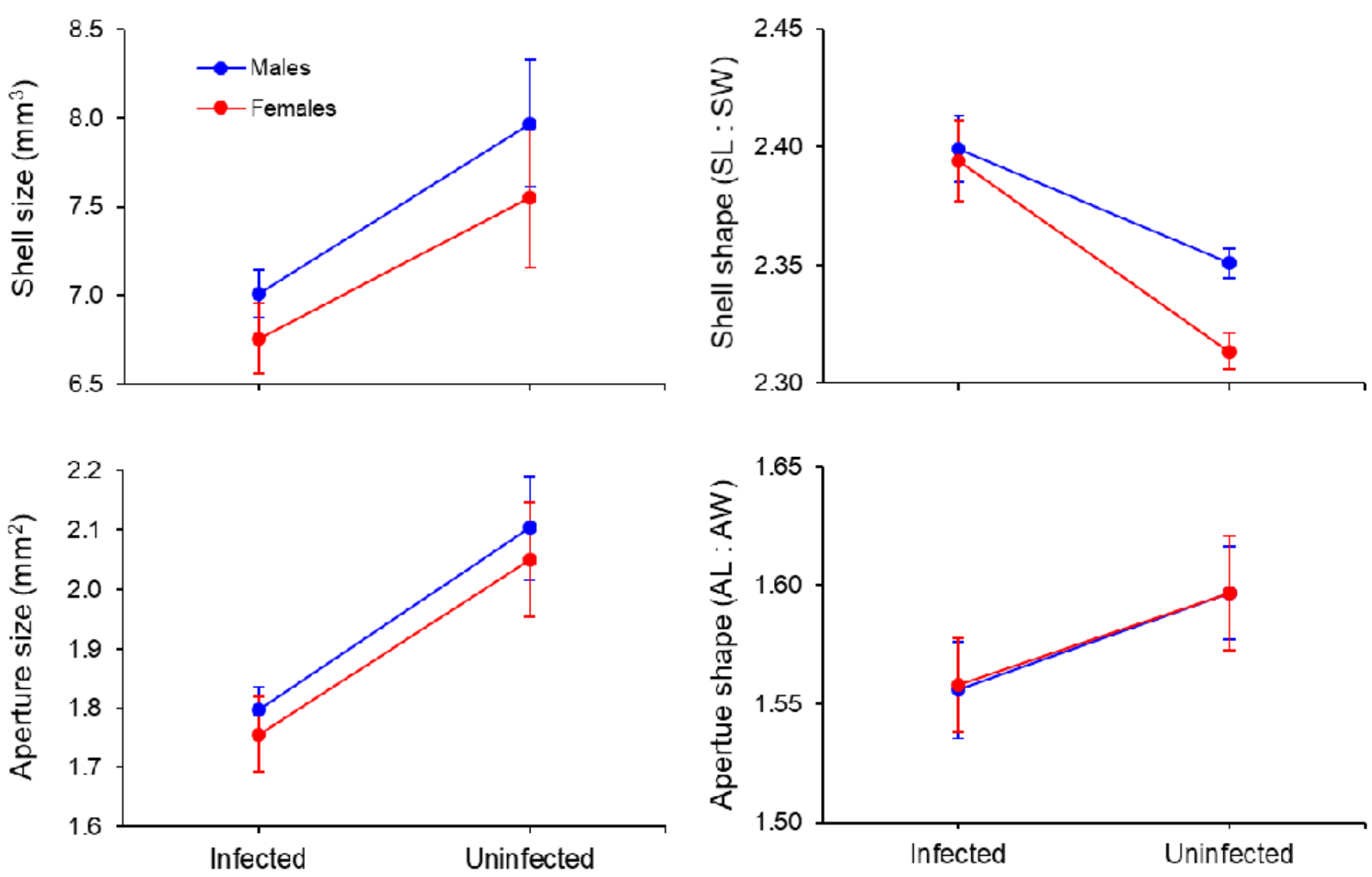

Figure 4. 


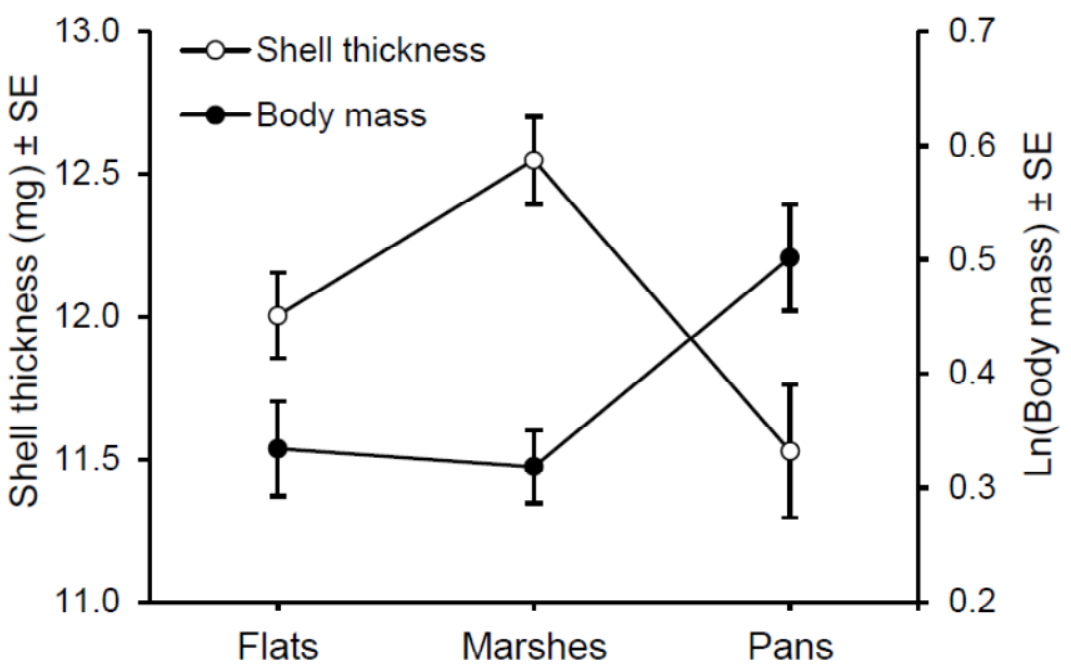

\section{Figure 5.}




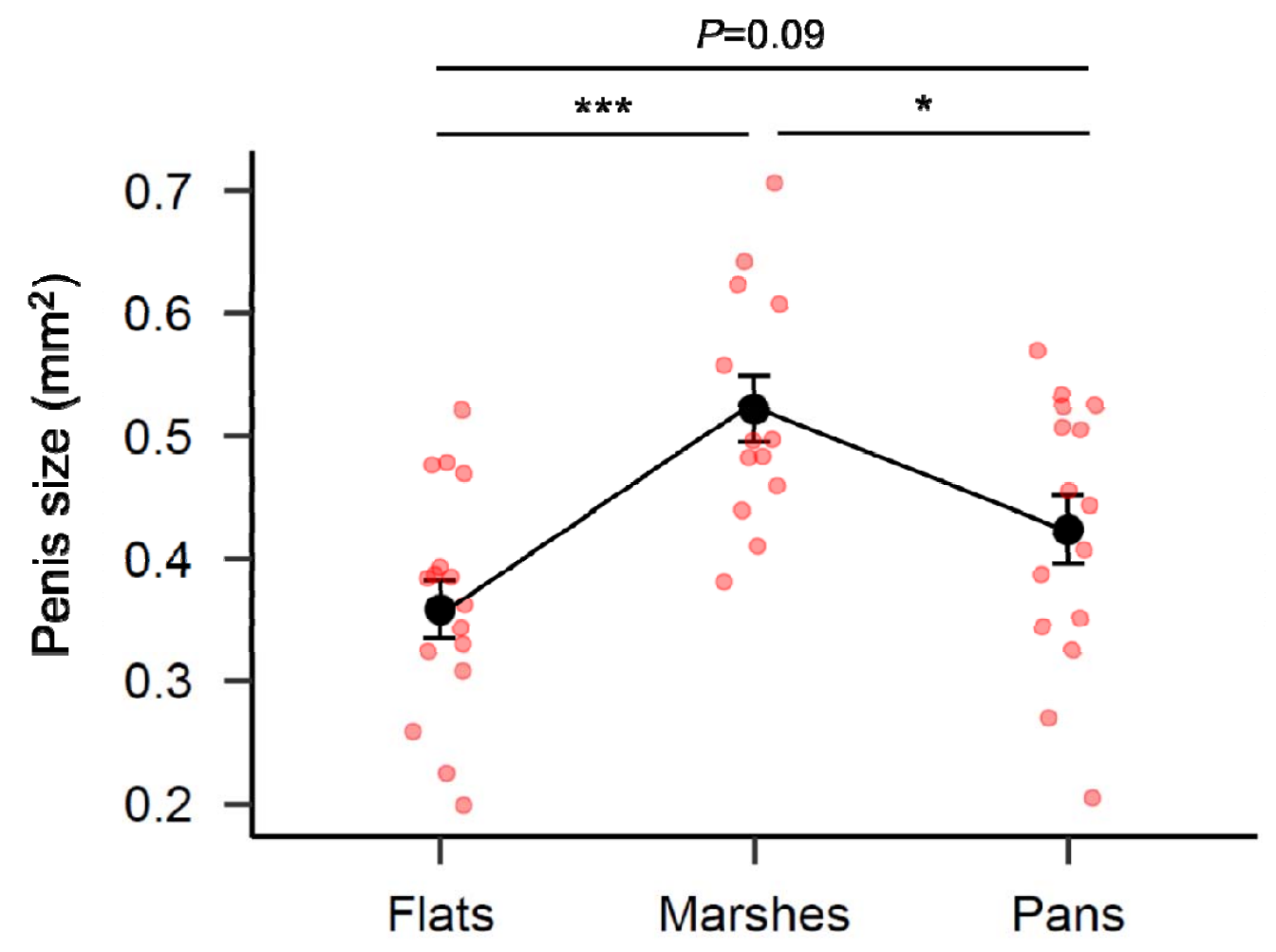

$114 \quad$ Figure 6. 
bioRxiv preprint doi: https://doi.org/10.1101/2020.10.06.327767; this version posted June 14,2021 . The copyright holder for this preprint (which was not certified by peer review) is the author/funder. All rights reserved. No reuse allowed without permission.

\section{$115 \quad$ Figure 7.}
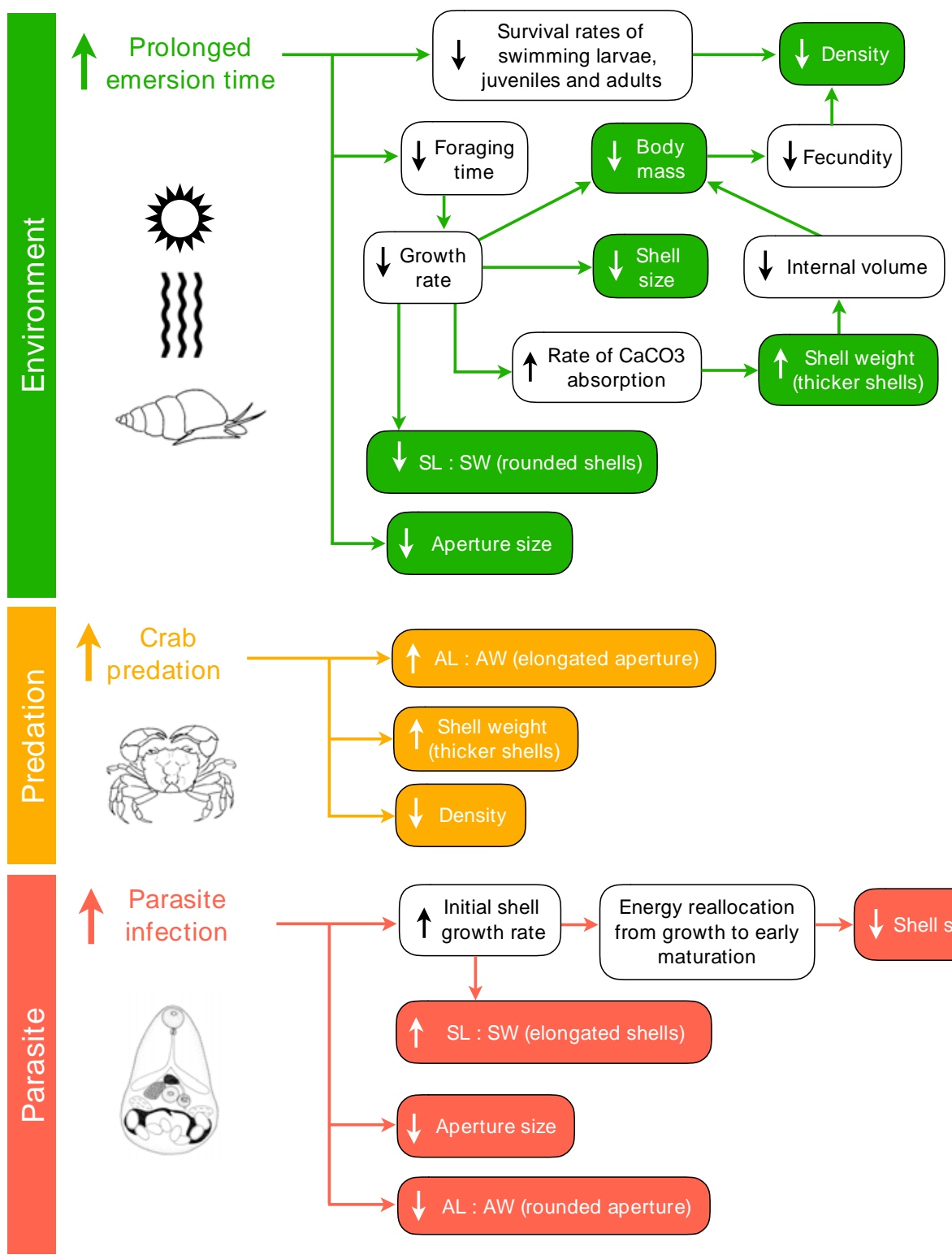